Н.В. Данилова

\title{
МАТЕРИАЛЬНО-ТЕХНИЧЕСКИЕ РЕСУРСЫ ЗДРАВООХРАНЕНИЯ
}

Учебное пособие

Под редакцией профессора, академика РАН В.И. Стародубова 
УДК 614.201

ББК 5*65 2/4-65.9

Д18

\begin{abstract}
Рецензенты:
Дубынина Е.И. - доктор медицинских наук, профессор кафедры экономики, управления здравоохранения и медицинского страхования ФДПО ФГБОУ ВО «Российский национальный исследовательский медицинский университет им. Н.И. Пирогова» Минздрава России;

Милушкина О.Ю. - доктор медицинских наук, доцент, Учёный секретарь ФГБОУ ВО «Российский национальный исследовательский медицинский университет им. Н.И. Пирогова» Минздрава России.
\end{abstract}

\title{
Данилова Н.В.
}

Д18 Материально-технические ресурсы здравоохранения: учебное пособие / под ред. проф., акад. РАН В.И. Стародубова. М.: Издательский дом Академии Естествознания, 2019. - 60 с.

\section{ISBN 978-5-91327-582-0 \\ DOI 10.17513/np.356}

Учебное пособие подготовлено для использования в профессиональном обучении и последипломной подготовке специалистов в составе цикла дисциплин по специальности «Организация здравоохранения и общественное здоровье». Соответствует основной образовательной программе послевузовского обучения (уровень ординатуры). Содержит теоретическую часть, контрольные вопросы, официальные и прикладные источники для более глубокого усвоения знаний в аудиторных и самостоятельных занятиях. Материал книги может быть полезен преподавателям, студентам, аналитикам, работникам финансовой службы медицинских организаций в целях координации медицинской и экономической деятельности.

ISBN 978-5-91327-582-0

(C) Данилова Н.В., 2019

(с) ИД «Академия Естествознания»

(C) АНО «Академия Естествознания» 


\section{ОГЛАВЛЕНИЕ}

ВВЕДЕНИЕ 4

ГЛава 1. СИСТЕМА ЗДРАВООХРАНЕНИЯ КАК СУБЪЕКТ НАЦИОНАЛЬНОЙ ЭКОНОМИКИ И ГОСУДАРСТВЕННОГО НАБЛЮДЕНИЯ ПО ВИДАМ ДЕЯТЕЛЬНОСТИ …….........................................................

1.1. Определение ресурсов, их группировка и формирование в здравоохранении.........................................6

1.2. Обеспечение здравоохранения ресурсами в условиях их ограниченности .................................................. 10

1.3. Материально-технические ресурсы системы здравоохранения

ГЛАВа 2. ХАРАКТЕРИСТИКИ И ПОКАЗАТЕЛИ МАТЕРИАЛЬНОТЕХНИЧЕСКИХ РЕСУРСОВ ЗДРАВООХРАНЕНИЯ

2,1. Структура и состав материально-технической базы здравоохранения

2.2. Показатели материально-технического обеспечения системы здравоохранения

ГЛава 3. ТЕХНИЧЕСКИЕ РЕСУРСЫ, МАТЕРИАЛЬНО-ТЕХНИЧЕСКИЙ МЕНЕДЖМЕНТ МЕДИЦИНСКИХ ОРГАНИЗАЦИЙ

3.1. Индикаторы состояния и использования ресурсов медицинской организации 33

3.2. Оценка состояния медицинской техники и результативности ее использования 38

3.3. Управление материальными ресурсами медицинской организации

ГЛава 4. ОСНОВЫ ПАСПОРТИЗАЦИИ МЕДИЦИНСКИХ ОРГАНИЗАЦИЙ, МЕДИЦИНСКАЯ СТАТИСТИКА МАТЕРИАЛЬНЫХ И ТЕХНИЧЕСКИХ РЕСУРСОВ

4.1. Роль паспортизации медицинских организаций в управлении материальными ресурсами .45

4.2. Статистика материально-технической обеспеченности системы здравоохранения .48

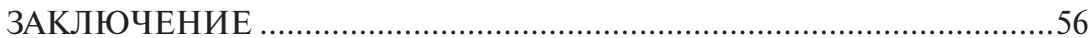

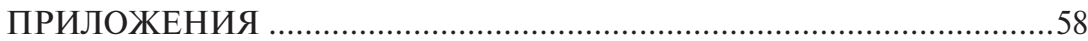




\section{ВВЕДЕНИЕ}

Ресурсное обеспечение системы здравоохранения, каждой медицинской организации является ведущим структурным компонентом, повышающим доступность и качество медицинской помощи разных видов и форм оказания. Воспроизводство и поддержание здоровья граждан рассматривается с позиции одного из видов экономической деятельности, в которой основополагающая триада ресурсов - человеческие, материально-технические, финансовые, объединяются в производственном процессе с целью достижения конечного продукта - реализации оказания медицинской помощи населению. В характеристике и сущности всех видов ресурсов заложена потенциальная возможность их участия в медицине и организации здравоохранения в качестве производственных факторов экономики, трансформируясь, в ходе потребления, в потребительские ресурсы.

Экономический менеджмент сферы здравоохранения включает затраты на производство, рабочий процесс и выпуск продукции по оказанию диагностических, лечебных, реабилитационных, профилактических, медико-социальных, вспомогательных услуг. Это позволило внести раздел «Здравоохранение и предоставление социальных услуг» в состав общероссийского классификатора видов экономической деятельности -ОКВЭД (в ред. Изменения № 1/2007), являющегося частью национальной системы стандартизации Российской Федерации.

Руководители медицинских организаций, менеджеры, специалисты в области экономики и финансирования медицинских организаций в своей текущей и перспективной работе нуждаются в знании основ ресурсного обеспечения системы здравоохранения (кадровое, материально-техническое, финансовое, технологическое, информационное), их взаимосвязей и взаимовлияния. Среди важнейших сфер интеграции - возможности и перспективы ресурсного воздействия на соблюдение критериев и регламентов качества медицинской помощи по уровням ее оказания и на общественное здоровье в целом.

К одному из самостоятельных видов ресурсного обеспечения в большинстве социально-экономических систем, в том числе, здравоохранения, относятся материально-технические ресурсы - особая 
форма, которая формирует инфраструктуру медицинских организаций. Материальная база рассматривается с позиции основных и оборотных фондов, включая медицинское оборудование, технику, приборы, то есть, в совокупности - медицинские изделия. Способы расчета параметров их функционирования с интерпретацией динамики изменений позволяют анализировать и совершенствовать работу медицинских организаций, осуществлять оперативное и прогностическое управление в целях улучшения качества, результативности и эффективности сферы здравоохранения.

Представленный материал содержит основную информацию о теоретических основах материального и технического обеспечения в разрезе здравоохранения как системы и применительно к каждой медицинской организации. Рассмотрены вопросы медицинской статистики материально-технических ресурсов, расчета показателей их состояния, навигации, распределения и использования. Выделены аспекты учета, инвентаризации материальных объектов, скрининга организационных и технологических процессов применительно к внедрению в медицинских организациях принципов отзывчивости, бережливости в ракурсе их обновления.

Учебное пособие составлено в соответствии с программой дисциплины «Организация здравоохранения и общественное здоровье» и предназначено для лиц, получающих дополнительное образование по программам профессиональной переподготовки, разработанным на основании квалификационных требований, профстандартов и государственных образовательных стандартов высшего образования. 


\section{Гдава 1. СИСТЕМА ЗДРАВООХРАНЕНИЯ КАК СУБЪЕКТ НАЦИОНАЯЬНОЙ ЭКОНОМИКИ И ГОСУДАРСТВЕННОГО НАБЛЮДЕНИЯ ПО ВИДАМ ДЕЯТЕДЬНОСТИ}

\section{1. Определение ресурсов, их группировка и формирование в здравоохранении}

Обеспеченность ресурсами системы здравоохранения является основой улучшения здоровья, повышения отзывчивости и ответственности этой медико-социальной сферы к растущим потребностям населения Российской Федерации в оказании различных видов медицинской помощи.

В понятие ресурсы (от франц. resources) включают средства, запасы, источники средств, доходы. При использовании в экономической науке и практике, данный термин обозначает не только сырье, землю и труд, но и конечный продукт труда, поскольку продукция одной деятельности нередко является ресурсом для другого вида производства. Различают ресурсы восполняемые, такие как - постоянно выпускаемая продукция, цикловое обучение работников и невоспроизводимые источники (например, запасы природных ископаемых). Эта дифференциация достаточно условна, ведь высококвалифицированные кадры можно рассматривать как уникальный ресурс в течение длительно периода времени.

Общепринятой классификации ресурсов не существует. В экономических и экономико-математических моделях выделяют их следующие виды: природные; средств производства (производственные мощности, предметы трудовой деятельности); трудовые (по группам населения, их квалификационному и профессиональному распределению); финансовые (капитальные вложения, кредиты и другие); конечных потребительских благ (непроизводственные мощности, продукция для индивидуального и общественного потребления).

Основными ресурсами системы здравоохранения являются:

кадровые (медицинские работники, имеющие медицинское или иное образование, в трудовые (должностные) обязанности которых входит осуществление медицинской деятельности; либо физические лица, являющиеся индивидуальными предпринимателями, непосредственно 
осуществляющими медицинскую деятельность (Федеральный закон от 21.11.2011 № 323-Ф3, ст. 2, п. 13);

финансовые (денежные средства в распоряжении сектора здравоохранения на федеральном, региональном, муниципальном уровне, в подведомственных медицинских организациях);

материально-технические средства (здания, сооружения, где размещены медицинские организации, их инфраструктура, транспорт);

технологические (технологии, с помощью которых осуществляются как процедуры, манипуляции, операции при проведении диагностики, лечения, реабилитации, профилактики, так и комплексная организация этих процессов в целом); В качестве технологической составляющей при выполнении работ (услуг), являющейся компонентом медицинской деятельности, выступают телемедицинские или информационные технологии. Они обеспечивают дистанционное взаимодействие медицинских работников с пациентами, их законными представителями, идентификацию и аутентификацию указанных лиц, документирование совершаемых ими действий при проведении консилиумов, консультаций, дистанционного медицинского наблюдения за состоянием здоровья пациента) (в ред. Федерального закона от 29.07.2017 № 242-Ф3, статья 2, п. 22 ).

Практически все перечисленные ресурсы, по своей сути, относятся к материальным активам. Нематериальным компонентом ресурсного обеспечения является научно-практическая продукция: публикации, патенты и авторские свидетельства (изобретения), медицинские, организационные, информационные технологии как своего рода «ноу-хау» в форме интеллектуального продукта работников медицинской организации в системе здравоохранения.

В здравоохранении ресурсы являются необходимым элементом процесса предоставления медицинской помощи и производства медицинских услуг. На сохранение, укрепление, восстановление здоровья государство затрачивает большие финансовые средства, что позволяет рассматривать это понятие в качестве экономической категории, а систему здравоохранения считать ресурсоемкой областью, использующей значительный арсенал как медицинских, так и экономических, методов.

Поэтому здравоохранение рассматривается как один из видов экономической деятельности, классифицированный в общероссийском классификаторе видов экономической деятельности в качестве группировки этих видов в области здравоохранения (ОКВЭД 2, раздел Q. 86). В целесообразном, соизмеримом и рациональном использовании ресурсов 
заинтересованы все субъекты экономических отношений с позиции, прежде всего результативности деятельности.

Система здравоохранения, как любая социальная сфера, способна выполнять свои общественные и персонализированные функции (наиболее близкие к конкретному человеку, личности) лишь благодаря наличию соответствующих средств и их качественных характеристик. Функционирование здравоохранения, как одного из элементов социального пространства, является, по сути, обменом услугами и ресурсами. Общество предоставляет определенные и разнообразные средства (ресурсы) в распоряжение системы здравоохранения, В процессе их использования, с помощью специальных методов и методик (как отдельных услуг, так и медицинской помощи в целом), исходный потенциал преобразуется в целевой ресурс - общественное здоровье, являющееся, с позиции глобальной оценки, национальной безопасностью страны. Поэтому проблемы здравоохранения, в ракурсе решения его экономических проблем, рассматриваются в последние десятилетия на государственном уровне.

Экономическая деятельность имеет место тогда, когда ресурсы объединяются в единый производственный процесс, имеющий целью производство профильной продукции (услуг) с достижением реальных результатов в процессе их предоставления. К основным результирующим параметрам, отражающим состояние общественного здоровья и здравоохранения в стране и позволяющим сопоставлять его с обстановкой, сложившейся в мире, относятся цели и установленные целевые показатели Национального проекта Российской Федерации «Здравоохранение» на 2018-2024 годы (табл. 1).

В области материально-технического оснащения и улучшения инфраструктуры системы здравоохранения в реальном будущем намечены ряд мер. Среди них: завершить формирование сети медицинских организаций первичного звена здравоохранения с использованием геоинформационной системы; построить врачебные амбулатории, фельдшерские и фельдшерско-акушерские пункты в поселениях с численностью жителей от 100 человек до 2 тыс. человек, а также - использовать мобильные медицинские комплексы в населенных пунктах с численностью жителей менее 100 человек; внедрить инновационные медицинские технологии, включая систему ранней диагностики и дистанционный мониторинг состояния здоровья пациентов; завершить формирование сети национальных медицинских исследовательских центров; создать современную инфраструктуру оказания медицинской помощи детям. 
Таблица 1

Планируемый уровень достижения показателей цели и результатов

\begin{tabular}{|l|c|}
\hline \multicolumn{1}{|c|}{ Показатель } & Значение в 2024 г. \\
\hline $\begin{array}{l}\text { Увеличение ожидаемой продолжительности жизни при } \\
\text { рождении }\end{array}$ & \multicolumn{1}{|c|}{ До 78 лет } \\
\hline $\begin{array}{l}\text { Снижение смертности населения трудоспособного возраста } \\
\text { До } 350 \text { на } 100 \text { тыс. } \\
\text { трудосп. населения }\end{array}$ \\
\hline $\begin{array}{l}\text { Снижение смертности от болезней системы кровообращения } \\
\text { знижение смертности от новообразований, в том числе от }\end{array}$ & $\begin{array}{c}\text { До } 185 \text { на } 100 \text { тыс. } \\
\text { населения } 100 \text { тыс. }\end{array}$ \\
\hline Снижениения младенческой смертности & $\begin{array}{c}\text { До } 4,5 \text { случая на } \\
1 \text { тыс. родившихся }\end{array}$ \\
\hline
\end{tabular}

Достижение намеченных результатов по перечисленным направлениям развития здравоохранения, в значительной степени, будут определяться сбалансированностью экономической, финансовой и социальной политики государства, темпом роста валового внутреннего продукта, инвестиций в экономику, расходов на социальные нужды из бюджетов всех уровней, мерами по выравниванию социально-экономического развития российских регионов.

При благоприятной динамике решения стоящих перед страной вызовов, приоритетными направлениями государственной политики в обеспечении здоровья станут: создание механизмов взаимодействия медицинских организаций на основе единой государственной информационной системы в сфере здравоохранения (ЕГИСЗ); развитие детского здравоохранения, совершенствование системы оказания первичной медико-санитарной помощи, в том числе, развитие экспорта медицинских технологий и услуг.

Условием и гарантом выполнения поставленных задач явится улучшение и развитие материально-технической оснащенности медицинских организаций как основы укрепления инфраструктуры системы здравоохранения в целом. 


\section{2. Обеспечение здравоохранения ресурсами в условиях их ограниченности}

Основная проблема, связанная с обеспеченностью системы здравоохранения ресурсами заключается в их ограниченности, что имеет место не только в развивающихся, но и в индустриально и технологически развитых государствах. По материалам Всемирной организации здравоохранения ни одна из современных стран не имеет таких ресурсных запасов, которые были бы достаточными для покрытия потребностей национальных систем здравоохранения. Оптимизация их расходования является общемировой задачей.

Поскольку потребности человека, особенно при развитии новых медицинских технологий, неуклонно возрастают, ограниченность ресурсов, их обеспечивающих, обусловливает необходимость выбора адекватных экономических действий. Цена решения вопроса в том, какие виды медицинских услуг следует производить, какими видами ресурсов они будут обеспечены, для кого предназначены и главное - как они будут распределены. Оптимизация распределения ресурсных средств, по мнению известного отечественного ученого, академика С.П.Капицы, озвученному в средствах массовой информации, является более актуальной, нежели вопрос их ограниченности.

К началу третьего тысячелетия во многих развитых странах мира стала использоваться оценка методов диагностики и лечения не только с точки зрения доказательной медицины, но и с позиции адекватного расходования ресурсов на их внедрение, то есть - по экономическим результатам.

При этом, экономические итоги рассматриваются в виде нескольких составляющих - техническая (определение минимума материальных ресурсов для достижения результата), продуктивная (выявление наилучшего варианта из альтернативных ресурсов), распределительная (изучение оптимального распределения ресурсов в экономике), т.е. - в системе здравоохранения страны, региона, по медицинским организациям. О значимости предложенных критериев оценки свидетельствует факт присуждения (2009 г.) Нобелевской премии иссле-

довательнице Э. Остром (США) за анализ экономического управления ресурсами в разрезе коллективных действий.

Здравоохранение как система, призванная решать различные задачи, имеет прямое отношение к повышению эффективности использования 
ресурсов. В национальном масштабе оценка экономической эффективности рассматривается, в том числе, в аспекте направленности на объект деятельности и потенциальных преимуществ от проведенных мер (табл. 2).

Таблица 2

Уровни и способы определения экономической эффективности

\begin{tabular}{|l|l|}
\hline \multicolumn{1}{|c|}{$\begin{array}{c}\text { Уровень экономической } \\
\text { эффективности }\end{array}$} & \multicolumn{1}{c|}{$\begin{array}{c}\text { Направленность эффективности } \\
\text { при оказании медицинской помощи }\end{array}$} \\
\hline Индивидуальный & Конкретный пациент \\
\hline Семейный (домохозяйства) & Малообеспеченные семьи и семьи социального риска \\
\hline Медицинской организации & $\begin{array}{l}\text { Отбор адекватных технологий соотносительно } \\
\text { базовых ресурсов }\end{array}$ \\
\hline Муниципальный & \begin{tabular}{l} 
Распределение ресурсов без дублирования помощи \\
\hline Субъектовый
\end{tabular} \\
$\begin{array}{l}\text { Распределение видов и объемов помощи по } \\
\text { условиям оказания на основе территориальных } \\
\text { медико-демографических, показателей заболевае- } \\
\text { мости населения }\end{array}$ \\
\hline Федеральный & $\begin{array}{l}\text { Объемы ресурсов здравоохранения с учетом по- } \\
\text { требности населения, демографического прогноза, } \\
\text { возникновений рисков }\end{array}$ \\
\hline
\end{tabular}

Нельзя не учесть, что реализация задач по ресурсному наполнению сферы здравоохранения тесно сопряжена с возможными рисками, возникающими на общемировом и национальном уровне. В макроэкономическом аспекте они представлены замедлением темпов роста экономики, снижением инвестиционной активности, дефицитом финансирования из всех источников, возможными чрезвычайными ситуациями, ухудшением геополитической, как мировой, так и внутригосударственной ситуации.

На общероссийском уровне имеет значение нецелевое использование ресурсов, которое, с одной стороны, не позволяет обеспечить динамическое развитие системы здравоохранения, с другой - отвлекает их от применения в других областях экономики. При этом, дефицитность 
существующих ресурсов (включая материально-технические средства), обладая всеобъемлющим фундаментальным характером, формирует в современном обществе направленность к принятию мер по возможному их восполнению и последуюшему рациональному использованию (распределению) и ресурсосбережению.

Рационирование потребления ресурсов системой здравоохранения предусматривает сопоставление расходов на медицинские услуги и, в целом - на предоставленный объем медицинской помощи с итогами, выявленными при их оказании. Наилучший результат, полученный при меньших расходах, свидетельствует об оптимальном использовании ресурсов при производстве единицы продукции. Медико-социальная результативность рассматривается с позиции снижения случаев заболеваемости, инвалидизации и инвалидности, смертности населения, увеличения продолжительности жизни и ее качества.

В секторе здравоохранения материально-технические ресурсы, как и все их виды, выступают элементом производства медицинских услуг и медицинской помощи в целом. Согласно определению Федерального закона № 323-Ф3 (ст. 2) «медицинская услуга - медицинское вмешательство или комплекс медицинских вмешательств, направленных на профилактику, диагностику и лечение заболеваний, медицинскую реабилитацию и имеющих самостоятельное законченное значение».

Номенклатура медицинских услуг, построенная по иерархическому принципу, состоит из наименований с систематизированным перечнем кодов. Коды квалифицируются либо раздельно по видам вмешательств - простые, неделимые, или - в форме комплекса сложных услуг по профилактике, диагностике, лечению, медицинской реабилитации, оздоровлению, транспортной эвакуации пациента. По условиям оказания медицинской помощи выделяют услуги в амбулаторных, стационарных, санаторно-курортных условиях, скорой и неотложной медицинской помощи, организациях медико-социального ухода. При планировании видов и объемов медицинской деятельности основное внимание уделяется достижению результата от выполнения медицинских услуг, максимального, для вложенных в них средств по наиболее актуальным в каждом регионе видам медицинской помощи. 


\section{3. Материально-технические ресурсы системы здравоохранения}

Одной из важнейших характеристик любого сектора экономики является состояние и использование его материально-технической базы.

Материальными составляющими системы здравоохранения в целом и ее медицинских организаций являются основные и оборотные фонды (средства, активы). К основным фондам (ОФ) относят «произведенные активы, используемые неоднократно или постоянно в течение длительного периода, но не менее одного года для производства и оказания услуг». Определение данного термина содержится в общероссийском классификаторе основных фондов (ОКОФ), являющимся нормативным документом в области стандартизации.

ОФ составляют здания, сооружения, оборудование, больничные койки, медицинские приборы и аппараты, инструментарий, транспортные средства.

Медицинские организации, расположенные на конкретной административной территории (муниципальной, субъектовой, региональной, федеральной) составляют ее сеть - территориальную инфраструктуру.

В процессе своей эксплуатации ОФ, с учетом своего физического износа, постепенно переносят исходную стоимость на стоимость оказываемых медицинских услуг. Данные о наличии основных средств приводятся по полной учетной стоимости, с учетом проводившихся переоценок, которая равна сумме учитываемых в бухгалтерских балансах остаточной балансовой стоимости основных фондов и величины накопленного износа.

Оборотные фонды представлены материальными предметами краткосрочного (12 месяцев и менее) применения. Среди них: расходные материалы, лекарственные средства, мягкий медицинский инвентарь, продукты питания пациентов и прочие средства, стоимость которых переносится на стоимость выполненных медицинских услуг в течение года (табл. 3). В них входят как предметы трудовой деятельности, так и средства труда с учетом готового продукта (услуг).

Все виды средств (активов) отражаются в натуральном (количественном) и стоимостном (денежном) выражении. Продолжительность их жизненного цикла позволяет выделить среди основных средств - nассивную (здания и сооружения) и активную часть основных фондов (медицинская техника и оборудование). 


\section{Ведущие составляющие материально-технических средств}

\begin{tabular}{|l|l|}
\hline \multicolumn{1}{|c|}{ Основные фонды } & \multicolumn{1}{|c|}{ Оборотные фонды } \\
\hline $\begin{array}{l}\text { Сеть медицинских организаций } \\
\text { (инфраструктура в целом) }\end{array}$ & $\begin{array}{l}\text { Медикаменты (лекарственные средства) } \\
\text { Здания, сооружения, машины } \\
\text { Кродукты питания } \\
\text { Техний фонд, пациенто-места } \\
\text { Медицинское оборудование } \\
\text { Транспорт }\end{array}$ \\
Инвентарь (мягкий, хозяйственный, \\
канцелярский)
\end{tabular}

Сеть медицинских организаций формируется в соответствии с их номенклатурой. Ее развитие в российских регионах происходит и базируется на основе структуры и уровня заболеваемости, смертности населения, его половозрастного состава, климатических, географических особенностей территорий и транспортной доступности медицинских организаций.

Статистическая информация, отражающая структурные показатели состояния материально-технических ресурсов и показатели объемов помощи, которые предоставляются с их использованием, регистрируются в отчетных формах государственного статистического наблюдения. Форма ГСН № 30 включает ежегодные сведения по всем медицинским организациям, подведомственным Минздраву России, форма № 47 - о сети организаций, расположенных на территории российских субъектов, Российской Федерации в целом.

Фактическое состояние материальной ресурсной базы здравоохранения предусматривает оценку ее базиса в целом и по отдельным компонентам. Решение такой задачи облегчает классификация материальных и технических ресурсов, которая позволяет группировать объекты по ведущим характеристикам и признакам с определением их роли и места в совокупном обеспечении не только медицинской организации, но и ведомства (экономического вида деятельности) в целом (табл. 4).

Разработка действующего, в настоящее время, классификатора - ОКОФ (ОК 013-2014) предусмотрела его гармонизацию с Системой Национальных Счетов ООН (СНС 2008), Европейской комиссии, а также - Организации экономического сотрудничества и развития, Международного валютного фонда, Группы Всемирного банка и Общероссийского 
классификатора продукции по видам экономической деятельности. Это позволило перейти на общемировую классификацию и международные сопоставления с оценкой объемов, состава и состояния ОФ, реализацией системы их учета, определением основных экономических характеристик и рекомендательных нормативов проведения капитальных ремонтов ОФ. Наименования ОФ в ОК 013-2014, соответствующие их видам по международной системе национальных счетов (СНС) 2008, представлены в табл. 5.

Та блица 4

\section{Классификационные группы материальных ресурсов по признакам принадлежности к данным группам}

\begin{tabular}{|l|l|}
\hline \multicolumn{1}{|c|}{$\begin{array}{c}\text { Признак принадлежности } \\
\text { к группе }\end{array}$} & \multicolumn{1}{|c|}{$\begin{array}{c}\text { Группы материальных ресурсов } \\
\text { по экономической принадлежности }\end{array}$} \\
\hline Влияние на объект деятельности & Активные. Пассивные. \\
\hline Правовая принадлежность & Собственные. Арендованные \\
\hline Функциональность & Производственные. Непроизводственные. \\
\hline Степень функционирования & $\begin{array}{l}\text { Готовы к работе. Действующие. Находятся на } \\
\text { консервации. Простой (ремонт, реконструкция) }\end{array}$ \\
\hline Ведомственная принадлежность & $\begin{array}{l}\text { Промышленность. Сельское хозяйство. Тор- } \\
\text { говля. Связь. Транспорт. Строительство. ЖКХ. } \\
\text { Здравоохранение. Образование. Культура. }\end{array}$ \\
\hline $\begin{array}{l}\text { Признак принадлежности } \\
\text { к группе }\end{array}$ & $\begin{array}{l}\text { Группы материальных ресурсов по экономи- } \\
\text { ческой принадлежности }\end{array}$ \\
\hline $\begin{array}{l}\text { Сроки функционирования } \\
\text { (экплуатации) }\end{array}$ & $\begin{array}{l}10 \text { классификационных групп основных } \\
\text { средств }\end{array}$ \\
\hline $\begin{array}{l}\text { Натурально-вещественные } \\
\text { характеристики }\end{array}$ & Группы отраслевого классификатора \\
\hline
\end{tabular}

Построение наименований ряда группировок ОКОФ (табл. 5) близка, но имеет некоторые отличия от СНС 2008, поскольку в отечественном классификаторе использована терминология, сложившаяся в практике национальной статистики. Так, учет национальных особенностей позволил включить в российский ОКОФ (группа «Машины и оборудование») - «хозяйственный инвентарь и другие объекты». 
Таблица 5

Гармонизация видов основных фондов по ОКОФ с международной системой национальных счетов (СНС 2008)

\begin{tabular}{|c|c|c|c|}
\hline \multicolumn{2}{|r|}{ CHC 2008} & \multicolumn{2}{|r|}{ ОКОФ } \\
\hline $\begin{array}{l}\text { Обозна- } \\
\text { чение }\end{array}$ & Наименование видов ОФ & Код & Наименование видов ОФ \\
\hline AN111 & Жилые здания & 100 & Жилые здания и помещения \\
\hline AN112 & Другие здания и сооружения & 200 & $\begin{array}{l}\text { Здания (кроме жилых) и со- } \\
\text { оружения }\end{array}$ \\
\hline AN 1121 & Нежилые здания & 210 & Здания (кроме жилых) \\
\hline AN 1122 & Другие сооружения & 220 & Сооружения \\
\hline AN 113 & Машины и оборудование & 300 & $\begin{array}{l}\text { Машины и оборудование, } \\
\text { включая хозяйственный ин- } \\
\text { вентарь и др. объекты }\end{array}$ \\
\hline AN 1131 & Транспортное оборудование & 310 & Транспортные средства \\
\hline AN 1132 & $\begin{array}{l}\text { Информационное, компью- } \\
\text { терное и телекоммуникаци- } \\
\text { онное оборудование }\end{array}$ & 320 & $\begin{array}{l}\text { Информационное, компью- } \\
\text { терное и телекоммуникацион- } \\
\text { ное (ИКТ) оборудование }\end{array}$ \\
\hline AN 1133 & $\begin{array}{l}\text { Другие машины и оборудо- } \\
\text { вание }\end{array}$ & 330 & $\begin{array}{l}\text { Прочие машины и оборудова- } \\
\text { ние, включая хозяйственный } \\
\text { инвентарь }\end{array}$ \\
\hline AN117 & $\begin{array}{l}\text { Продукты интеллектуальной } \\
\text { собственности }\end{array}$ & 700 & $\begin{array}{l}\text { Объекты интеллектуальной } \\
\text { собственности }\end{array}$ \\
\hline AN 1171 & $\begin{array}{l}\text { Научные исследования } \\
\text { и разработки }\end{array}$ & 710 & $\begin{array}{l}\text { Научные исследования и раз- } \\
\text { работки }\end{array}$ \\
\hline AN 1173 & $\begin{array}{l}\text { Компьютерное программное } \\
\text { обеспечение и базы данных }\end{array}$ & 730 & $\begin{array}{l}\text { Программное обеспечение } \\
\text { и базы данных }\end{array}$ \\
\hline AN 11731 & $\begin{array}{l}\text { Компьютерное программ- } \\
\text { ное обеспечение }\end{array}$ & 731 & Программное обеспечение \\
\hline AN 11732 & Базы данных & 732 & Базы данных \\
\hline AN 1179 & $\begin{array}{l}\text { Другие продукты интеллек- } \\
\text { туальной собственности }\end{array}$ & 790 & $\begin{array}{l}\text { Другие объекты интеллекту- } \\
\text { альной собственности }\end{array}$ \\
\hline
\end{tabular}


Достаточно сложный и многоаспектный процесс формирования экономических отношений в секторе здравоохранения и непосредственно в медицинских организациях, предусматривает основные направления в развитии и направлениях использования ресурсов, прежде всего - формирование их финансирования, создание системы управления ресурсами. При планировании диапазона видов и объемов медицинской деятельности внимание к рационированию при использовании ресурсов и произведенных затрат рассматривается с нескольких позиций. Прежде всего, достижение ожидаемого, от выполнения медицинских услуг, результата, а также - соотношения полученного медико-социального эффекта и вложенных в него средств, по сравнению с альтернативными вариантами, адекватного регионального распределения ресурсов для доступности медицинских услуг на любой территории с приоритетным расходованием средств на самые востребованные виды помощи.

\section{Контродьные вопросы}

1. Что такое ресурсы, каковы их виды, изучаемые как экономической наукой, так и - медицинской практикой?

2. Каковы задачи обеспечения системы здравоохранения и медицинских организаций ресурсами?

3. Для чего необходимы ресурсы, их классификация в системе здравоохранения. Перечислите материальные и нематериальные ресурсы.

4. Сформулируйте перспективную систему целей по сохранению общественного здоровья, поставленную на государственном уровне, планируемые показатели их достижения с помощью, в том числе, оптимизации ресурсного обеспечения здравоохранения.

5. Каковы причины возникновения проблемы ограниченности ресурсов и возможности ее решения в современном мире?

6. Охарактеризуйте понятия «основные» и «оборотные» материальные средства, материальные и нематериальные активы, активная и пассивная часть материально-технических ресурсов. В чем общность и отличия основных и оборотных фондов?

7. В каких показателях ведется оценка основных и оборотных фондов? 8. Какие отчетные статистические данные позволяют охарактеризовать состояние материально-технической базы медицинской организации, системы здравоохранения в целом? 
9. Что такое ОКОФ и какова гармонизация его структурных компонентов с международными показателями?

10. Перечислите основные направления развития и улучшения использования ресурсов.

\section{Официальные документы, нормативно-правовые акты}

\section{Литература}

1. «Об утверждении Государственной программы «Развитие здравоохранения»: Постановление Правительства РФ от 26.12.2017 № 1640 (в ред. от 24.01.2019) // СПС «КонсультантПлюс».

2. «О национальных целях и стратегических задачах развития Российской Федерации на период до 2024 года»: Указ Президента Российской Федерации от 07.05.2018 № 204 (в ред. от 19.07.2018 № 444) // СПС «КонсультантПлюс».

3. ОК 029-2014 (КДЕС.Ред.2) Общероссийский классификатор видов экономической деятельности: утвержден Приказом Россстандарта от 31.01.2014 № 14-ст, ред.от 29.03.2018 // СПС «КонсультантПлюс».

4. ОК 013-2014 (СНС 2008) Общероссийский классификатор основных фондов: утвержден и введен в действие приказом Росстандарта от 12.12.2014 № 2018-ст // СПС «КонсультантПлюс».

5. «Об утверждении номенклатуры медицинских услуг»: Приказ Минздрава России от 13.10.2017 № 804н.

6. «Об основах охраны здоровья граждан в Российской Федерации»: Федеральный закон от 21.11.2011 № 323-Ф3 (в ред. от 07.03.2018 № 56Ф3, ст. 2, п. 22).

7. Лопатников Л.И. Экономико-математический словарь. Словарь современной экономической науки. М.: Дело, 2003. С. 309.

Экономика здравоохранения. Учебное пособие. Санкт-Петербург: ГПМУ, 2015. $72 \mathrm{c}$.

8. Palmer S., Torgerson D.J. Definition of efficiency // BMJ. 1999. Vol. 318. P. $1136-1139$. 


\section{Гдава 2. ХАРАКТЕРИСТИКИ И ПОКАЗАТЕЯИ МАТЕРИАЯЬНО-ТЕХНИЧЕСКИХ РЕСУРСОВ ЗДРАВООХРАНЕНИЯ}

\section{2,1. Структура и состав материально-технической базы здравоохранения}

Материально-техническая база - один из видов обеспечения системы здравоохранения в совокупности с финансовыми, трудовыми, технологическими, информационными ресурсами. По значимости, несомненно, кадровый компонент ресурсного обеспечения, является самым весомым. Даже при условии гипотетически представленной идеальной картины будущего, где, в адекватной потребностям мере, будет присутствовать практически вся инфраструктура здравоохранения, но - без человеческого потенциала (медицинских кадров) - экономическая система не сможет функционировать. Необходимо единство взаимодействия и комплексное развитие всех видов ресурсов.

Показатели и состояние производственных (материально-технических) ресурсов являются ключевыми характеристиками научно-технического уровня инновационных и модернизационных процессов функционирования системы здравоохранения, призванными улучшить доступность и качество оказываемых медицинских услуг. В системе здравоохранения самым укрупненным компонентом, отражающим состояние материально-технических ресурсов и их основных фондов, является сеть медицинских организаций (МО).

Сеть МО - совокупность организационно и функционально связанных организаций, расположенных на определенной территории и предназначенных для оказания современных видов медицинской помощи населению. Сеть должна формироваться с учетом: состояния здоровья и потребности территориального населения в различных видах помощи; географических особенностей расселения жителей и развитости транспортной инфраструктуры региона; демографических особенностей численности и возрастно-половой структуры территориального населения. Особое значение в ее оценке приобретает обеспеченность медицинскими кадрами и состояние материально-технической базы входящих в сеть организаций.

Каждая МО в общей системе (сети) занимает свое функциональное место, выполняя соответствующие профессиональные функции. 
Структурное разнообразие сети отражено и определено в номенклатуре типов МО (приказ Минздрава России от 6 августа 2013 № 529н), оказывающих амбулаторную стационарную и иные виды помощи.

Номенклатура создана в целях формирования единой правоприменительной практики, объектом которой являются МО. В соответствии со статьей 2 Федерального закона № 323-Ф3, медицинской организацией является юридическое лицо независимо от организационно-правовой формы, осуществляющее в качестве основного (уставного) вида деятельности медицинскую деятельность на основании лицензии, выданной в порядке, установленном законодательством Российской Федерации.

Сеть МО содержит: больницы и поликлиники в том числе, специализированные для взрослого и детского населения; диспансеры, центры, санаторно-курортные организации; родильные дома, госпитали, медико-санитарные части, станции скорой медицинской помощи и другие лечебно-профилактические организации. В соответствии с общероссийским классификатором объектов административно-территориального деления (ОКАТО), в Российской Федерации «центры» не являются объектами классификации.

Присвоение МО наименования «центральный / центральная» может быть предусмотрено учредителем организации в зависимости от ее мощности, уровня материально-технического оснащения, численности коечного фонда. В наименовании организации содержится и ее административная подчиненность (федеральная, краевая, республиканская, областная, муниципальная, районная, городская МО).

Организации, имеющие право на оказание медицинской помощи, являющиеся юридическими лицами, подлежат государственной регистрации. Ее осуществляет федеральный орган исполнительной власти с присвоением МО основного государственного регистрационного номера (ОГРН) и возможностью включения в единый государственный реестр юридических лиц (ЕГРЮЛ). Медицинские организации, работающие в системе ОМС, регистрируются также в реестре территориального фонда в соответствии с утвержденными Правилами обязательного медицинского страхования.

Для обеспечения доступности медицинской помощи в организациях государственной и муниципальной системы здравоохранения, исходя из условий, видов оказания медицинских услуг, 
установления потребности субъектов Российской Федерации в этих объектах здравоохранения (одобренным распоряжением Правительства России от 19.10.1999 № 1683-р), утверждены требования к размещению МО (приказ Минздрава России от 27.02.2016 № 132н). Рекомендации служат ориентиром при построении сети организаций. Например, для станции скорой медицинской помощи, предоставляющей помощь вне медицинской организации, рекомендуется 50 тыс. жителей на 1 МО. Для диспансеров, предоставляющих помощь в амбулаторных, стационарных условиях, дневном стационаре, требуется не менее одной организации на каждый субъект РФ.

Параметры, установленные указанными требованиями, могут обоснованно корректироваться каждым российским субъектом с учетом транспортной доступности, климатических и географических особенностей, уровня и структуры заболеваемости, особенностей половозрастного состава территориального населения, возможности соблюдения порядков и клинических рекомендаций по оказанию медицинской помощи, а также - наличию плановых мощностей медицинских организаций, функционирующих в субъекте. Медицинские организации иных видов (не перечисленные в приказе) размещаются, по решению российского субъекта, при наличии потребности в них, в соответствии с профильными порядками оказания медицинской помощи.

Практические рекомендации по формированию сети медицинских организаций, работающих в амбулаторных и стационарных условиях, представлены в табл. 6 .

По такому же решению (в соответствии с порядками оказания медицинской помощи) в населенных пунктах с численностью жителей, составляющей меньше, указанного в Требованиях приказа № 132н, объема (от 10 до 20 тыс. человек), разрешено размешение нескольких врачебных амбулаторий или центров (отделений) общей врачебной практики (семейной медицины), либо - одной поликлиники. Медицинскую помощь во врачебных амбулаториях рекомендуется организовать по профилям «терапия», «акушерство-гинекология», «хирургия». Допускается расширение лечебных профилей при наличии условий и территориальной потребности во врачах других специальностей. 
Таблица 6

Рекомендуемая численность территориального населения по оказанию медицинской помощи основными типами организаций

\begin{tabular}{|c|c|c|}
\hline $\begin{array}{c}\text { Условия оказания ме- } \\
\text { дицинской помощи }\end{array}$ & $\begin{array}{c}\text { Тип медицинской } \\
\text { организации }\end{array}$ & $\begin{array}{l}\text { Число жителей, при- } \\
\text { крепленных к } 1 \text { МО }\end{array}$ \\
\hline \multirow[t]{7}{*}{$\begin{array}{l}\text { В амбулаторных } \\
\text { условиях (дневном } \\
\text { стационаре) }\end{array}$} & $\begin{array}{l}\text { Амбулатория (врачебная) } \\
\text { или центр (отделение) общей } \\
\text { врачебной практики }\end{array}$ & 1 на 2-10 тыс. человек \\
\hline & Поликлиника & 1 на 20-50 тыс. человек \\
\hline & Детская поликлиника & 1 на 10-30 тыс. детей \\
\hline & $\begin{array}{l}\text { Центр консультативно-диагно- } \\
\text { стический (или поликлиника) }\end{array}$ & 1 на 250 тыс. человек \\
\hline & $\begin{array}{l}\text { Центр консультативно-диа- } \\
\text { гностический (детский) или } \\
\text { поликлиника }\end{array}$ & 1 на 100 тыс. детей \\
\hline & $\begin{array}{l}\text { Поликлиника стоматологи- } \\
\text { ческая }\end{array}$ & $\begin{array}{l}\text { Не менее } 1 \text { на } 100 \text { тыс. } \\
\text { человек }\end{array}$ \\
\hline & $\begin{array}{l}\text { Детская стоматологическая } \\
\text { поликлиника }\end{array}$ & 1 на 20-50 тыс. детей \\
\hline \multirow{8}{*}{$\begin{array}{l}\text { В стационарных } \\
\text { условиях, в дневном } \\
\text { стационаре }\end{array}$} & Участковая больница & 1 на 5-20 тыс. человек \\
\hline & Городская больница & 1 на 20-300 тыс. человек \\
\hline & Детская городская больница & $\begin{array}{l}1 \text { на } 20-200 \text { тыс. } \\
\text { человек }\end{array}$ \\
\hline & Районная больница & 1 на 20-100 тыс. человек \\
\hline & $\begin{array}{l}\text { Краевая, республиканская, об- } \\
\text { ластная, окружная больница }\end{array}$ & $\begin{array}{l}\text { Не менее } 1 \text { на субъект } \\
\text { РФ }\end{array}$ \\
\hline & $\begin{array}{l}\text { Детская краевая, республи- } \\
\text { канская, областная, окружная } \\
\text { больница }\end{array}$ & $\begin{array}{l}\text { Не менее } 1 \text { на субъект } \\
\text { РФ }\end{array}$ \\
\hline & Больница инфекционная & Не менее 1 на субъект РФ \\
\hline & Больница инфекционная детская & 1 на 500 тыс. детей \\
\hline
\end{tabular}


Оптимизация сети МО реализуется на основе ее перспективного построения с учетом потребности территориального населения (городского и сельского) в медицинской помощи и, следовательно - в типологии, числе и мощности организаций, функционирующих на разных уровнях ее оказания. Расчетным элементом структуры МО для стационаров является условная минимальная функциональная единица мощности - не меньше 25-30 коек, для поликлиник - число посещений при полной нагрузке врача на врачебную должность в течение года работы (показатель функции врачебной должности). При отсутствии необходимой численности пациентов, обеспечивающих работу МО, в качестве альтернативы, предусматриваются: создание необходимого вида специализированной помощи на более высоком уровне ее оказания; медицинское зонирование территорий с организацией отделений или амбулаторных приемов для детского и взрослого населения из нескольких населенных пунктов их проживания.

Гарантом качества медицинской помощи является поддержание фондов организаций здравоохранения - основных и оборотных (как структурных элементов материальных ресурсов) в соответствии с техническими, санитарно-гигиеническими, технологическими требованиями к их устройству и эксплуатации. Основные фонды, жизненный цикл которых достаточно продолжителен, включают здания и дополнительные сооружения, а также их наполнение соответствующей инфраструктурой.

Здания и сооружения соотносят с пассивной частью, медицинскую технику и оборудование - с активной частью основных фондов. Оборотные фонды представлены компонентами и объектами с укороченным (до 12 мес.) жизненным циклом существования. Следует отметить, что после 2011 года законодательно утвердился термин «медицинские изделия» (Федеральный закон «Об основах охраны здоровья граждан» от 21.11.2011 № 323-Ф3, ст. 38).

\section{Видовая структура основных и оборотных фондов}

\section{Основные фонды}

Здания и сооружения

Коечный фонд

Техника (приборы, аппараты)

Медицинское оборудование, инструментарий

Транспорт
Оборотные фонды

Медикаменты Инвентарь (мягкий) Продукты питания Денежные средства на расчетных счетах 
Медицинскими изделиями «являются любые инструменты, аппараты, приборы, оборудование, материалы и прочие изделия, применяемые в медицинских целях отдельно или в сочетании между собой, а также вместе с другими принадлежностями, необходимыми для применения указанных изделий по назначению, включая специальное программное обеспечение и предназначенные производителем для профилактики, диагностики, лечения и медицинской реабилитации заболеваний, мониторинга состояния организма человека, проведения медицинских исследований, восстановления, замещения, изменения анатомической структуры или физиологических функций организма, предотвращения или прерывания беременности, функциональное назначение которых не реализуется путем фармакологического, иммунологического, генетического или метаболического воздействия на организм человека».

Принятая новая терминология, до настоящего времени, воспринимается рядом инженерно-технических специалистов неоднозначно, высказывается мнение о необходимости формулирования понятия «медицинская техника», поскольку нет полного совпадения и четкости в его разграничении с «медицинскими изделиями». Ведь к изделиям, сейчас относят стенты, изделия для восстановления тканей, импланты, трансплантаты, шовные материалы, которые могут реализоваться с использованием фармакологического пути воздействия на организм.

Медицинские изделия (МИ) разделяют на виды - в соответствии с номенклатурной классификацией медицинских изделий. Присваивает вид медицинскому изделию Росздравнадзор, размещая информацию на своем официальном сайте www.roszdravnadzor.ru в подразделе «Электронные сервисы» - «Государственный реестр медицинских изделий и организаций, осуществляющих производство и изготовление медицинских изделий».

С 2013 года введен в действие новый национальный стандарт видов МИ в целях актуализации кодирования, определения степени риска при их воздействии на организм человека. Таким образом, национальные потребности в изделиях формулируются в плане эффективности, качества, безопасности с учетом национальных и международных норм.

Вместе с тем, в отечественной системе здравоохранения сохраняется необходимость в обеспечении устойчивости деятельности в аспекте доступа к медицинским изделиям. В мире используется более 8000 их общих групп. Достаточно сложно без оценки потребностей в закупках и профилактическом обслуживании оптимизировать расходы на приобретение МИ․ Выбор

${ }^{1}$ Глобальный сайт Всемирной организации здравоохранения:http://www.who.int/ medical_devices/innovation/en. 
медицинской техники нуждается в научном подтверждении, обеспечении финансовыми средствами, потенциалом для результативного использования, возможностями мониторинга спроса для развития медицинских технологий, подготовки персонала по квалифицированному использованию конкретных видов медицинской техники и оборудования 2 .

\section{2. Показатели материально-технического обеспечения системы здравоохранения}

Анализ основных средств (фондов, активов) позволяет дать оценку состоянию материально-технической базы здравоохранения. Используются параметры компонентов основных средств (ОС) раздельно по их: пассивной части - здания и сооружения; активной - медицинского оборудования техники, приборов; автотранспорта. Структура ОС оценивается по их первоначальной и остаточной стоимости с определением показателей обновления и износа (в процентах от первоначальной стоимости), а так же - по данным расчета фондовооруженности медицинских работников и фондооснащенности медицинских организаций.

Фондооснащенность и фондовооруженность являются ведущими характеристиками основных фондов, отражающими материально-техническую обеспеченность здравоохранения и медицинских организаций.

Индикатор фондооснащенности МО свидетельствует о ее мощности и определяется соотношением стоимости всех основных фондов MO, приходящейся на единицу занимаемой ими площади. Этот показатель был запланирован к включению в Постановление Правительства Российской Федерации с нормативным значением 1000 руб./кв. метр (в окончательную редакцию не включен).

Фондовооруженность отражает уровень обеспеченности медицинских работников активной частью фондов, рассчитанной по соотношению их балансовой стоимости к среднесписочному числу медицинского персонала в организациях здравоохранения.

Результативность использования ОС определяется на основе расчета показателей:

фондоемкость, отражающей объем материальных затрат на единицу показателя результата медицинской деятельности (пролеченного пациента, предоставленную услугу);

${ }^{2}$ Сайт Европейского регионального бюро ВО3: http://www.euro.who.int/en/healthtopics/Health-systems/health-technologies-and-medicines/health-technologies Документационный центр ВО3. 
фондоотдача - показатель, обратный фондоемкости, определяемый по величине объема медицинской «продукции» (число пациентов, услуг), приходящейся на единицу стоимости материальных затрат.

Динамика перечисленных индикаторов (ежегодная, либо, как правило, за три года) позволяет уточнить направленность и масштабы функционирования системы здравоохранения на макроэкономическом уровне - в части адресного и целевого характера освоения (обновления) основных средств и, соответственно - обеспечения и оценки структурного компонента качества оказываемой медицинской помощи.

Износ и амортизация основных фондов. Изменения структуры ОС, выявляемые при сравнении величин начальной и остаточной стоимости, рассчитанные по их группам (здания и сооружения; оборудование, медицинская техника; автотранспорт) выявляют дефекты обновления, в виде повышения износа в целом по всем ОС. Определяется, в том числе, наличие дисбаланса: избыточное обновление одних групп и недостаточное - других компонентов основных фондов.

В идеальных условиях между износом и амортизацией глобальных различий нет, темп амортизации соответствует темпу износа (по времени и по суммам). В текущей деятельности объем износа может не соответствовать сумме амортизации. Различия обусловлены тем, что износ характеризуется утратой объектом ОС (например, зданием) своих физических качеств и уровня современных технических требований к эксплуатации объекта. К амортизации относят процесс переноса стоимости ОС на другие объекты учета в целях дальнейшего воспроизводства ОС. Т.е. износ характеризует в максимальной степени физические свойства объекта ОС, амортизация - экономическую сторону его применения. Некоммерческие организации чаще пользуются термином «износ», начисляя его в конце учетного года, исходя из установленного срока полезного использования объектов основных средств.

Если обратиться к терминологии по материально-технической базе в промышленном производстве, то износ основных фондов формулируется как частичная или полная утрата ими потребительских свойств и стоимости в процессе эксплуатации. Степень износа ОС - отношение накопленного (к определенной дате) величины износа ОС (разница полной учетной стоимости и остаточной балансовой стоимости) к полной учетной стоимости этих фондов на ту же дату, в процентах. Судя по терминологии и расчетным формулам, понятия износа и амортизации достаточно близки. 
Следует выделить и другие аспекты данного вопроса, прежде всего амортизацию, которая отражается как в бюджетном, так и - налоговом учете, при этом порядок включения в расчеты определенных статей не всегда идентичен. Бюджетный учет осуществляется в соответствии с Ф3 «О бухгалтерском учете», нормативными актами Минздрава России, Российской Федерации, Инструкция по бюджетному учету предусматривает начисление амортизации бюджетными организациями на объекты основных средств и нематериальных активов с отражением накопленных сумм на соответствующих счетах аналитического учета счета «Амортизация». Согласно Налоговому кодексу (ст. 256, п. 1, подпункт 1) имущество бюджетных организаций не подлежит амортизации, за исключением основных средств, приобретенных при осуществлении предпринимательской деятельности и используемых для такой деятельности. Противоречий бюджетного и налогового учета в этом нет: амортизация оборудования, приобретенного за счет средств бюджета и ОМС, не может быть учтена как расходы для налогообложения, при расчете налогооблагаемой прибыли. Для целей налогообложения амортизируемое имущество распределяется по амортизационным группам (табл. 7).

Таблица 7

\section{Сроки использования основных средств по группам}

\begin{tabular}{|l|l|}
\hline \multicolumn{1}{|c|}{ Амортизационные группы } & \multicolumn{1}{|c|}{ Срок полезного использования } \\
\hline Первая & От 1 года до 2 лет включительно \\
\hline Вторая & Свыше 2 лет до 3 лет включительно \\
\hline Третья & Свыше 3 лет до 5 лет включительно \\
\hline Четвертая & Свыше 5 лет до 7 лет включительно \\
\hline Пятая & Свыше 7 лет до 10 лет включительно \\
\hline Шестая & Свыше 10 лет до 15 лет включительно \\
\hline Седьмая & Свыше 15 лет до 20 лет включительно \\
\hline Восьмая & Свыше 20 лет до 25 лет включительно \\
\hline Девятая & Свыше 25 лет до 30 лет включительно \\
\hline Десятая & Свыше 30 лет \\
\hline
\end{tabular}


Эти сроки определяются налогоплательщиком самостоятельно на дату ввода объекта амортизируемого имущества и с учетом классификации основных средств.

По методике бюджетного (бухгалтерского) учета производится оценка структуры основных фондов (по первоначальной и по остаточной стоимости), показателей их износа и обновления (процент от первоначальной стоимости), а также фондовооруженности медицинских работников и фондооснащенности организаций.

Определение структуры основных фондов реализуется, в соответствии с классификацией, раздельно для зданий и сооружений, медицинского оборудования, автотранспорта, что позволяет выявить дефекты и дисбаланс обновления основных средств по этим группам. При избыточном обновлении одних групп и недостаточном - других, доля последних будет снижаться, а обновляемых избыточно - повышаться. Износ основных фондов определяется по отношению разницы первоначальной и остаточной стоимости к первоначальной стоимости как суммарно (по общему объему), так и - для каждой классификационной группы.

Показатель износа зданий и сооружений допускается в объеме $24 \%$, сохранение их состояния возможно при ежегодном обновлении на $1,6-3,0 \%$; для оборудования разрешена степень износа $50 \%$ с ежегодным обновлением 12,5-15\%; для автотранспорта допустим уровень износа в $60 \%$ при обновлении примерно на $20 \%$.

Показатель обновления основных фондов для зданий и сооружений рассчитывается как отношение средств, направленных на капитальный ремонт, реконструкцию и новое строительство зданий медицинских организаций $\mathrm{k}-$ первоначальной их стоимости. При расчете полученная цифра умножается на поправочный коэффициент 2,5 с учетом роста стоимости с 01.01.2007 по 01.01.2018 г. (в 2007 году была проведена переоценка основных фондов). Помимо этого, значительная часть зданий введена в эксплуатацию ранее 2007 года. Для других классификационных групп корректировка роста стоимости не используется.

Согласно стандарту бухгалтерского учета начисление амортизации объекта ОС производится с помощью выбора методов. Линейный равномерное начисление постоянной суммы амортизации на протяжении всего срока полезного использования актива; метод уменьшаемого остатка - годовая сумма амортизации определяется исходя из остаточной стоимости объекта на начало отчетного года и норме амортизации, 
исчисленной исходя из срока полезного использования этого объекта и коэффициента не выше 3. На объект стоимостью до 10 тыс. руб. начисление не проводится, при стоимости от 10 до 100 тыс. руб. включительно, амортизация начисляется в размере $100 \%$ первоначальной стоимости объекта при выдаче его в эксплуатацию. При способе списания стоимости по сумме чисел лет срока полезного использования, расчет производится исходя из первоначальной стоимости или текущей (восстановительной) стоимости (в случае проведения переоценки объекта ОС) по соотношению: в числителе - число лет, остающихся до конца срока полезного использования объекта, в знаменателе - сумма чисел лет такого использования.

В процессе управления оказанием медицинской помощи населению возрастает роль анализа эффективности использования основных фондов. Помимо уже перечисленных критериев приобретают значение определение времени работы и простоя оборудования, рационирование использования медицинской техники с учетом сменности производственной деятельности, проведения ремонтных и иных работ. Поскольку основную нагрузку медицинской организации обеспечивает техника и оборудование, рассматривается сравнение эффективного времени их работы с периодом, отработанным по фактическим данным. Результативность может быть оценена с позиции сопоставления планового и конкретно выполненного количества исследований.

Возможны иные подходы к оценке технической базы на основе восстановления и обновления основных фондов с расчетом соотношений: затраты на ремонт к балансовой стоимости фондов; объем закупок основных фондов к их стоимости; объем закупок к балансовой стоимости оборудования и к общим затратам организации за определенный период.

Экономическую результативность работы медицинской организации характеризуют также показатели использования помещений (площадей) и оборудования - финансовый оборот организации к балансовой стоимости ОС; число законченных случаев лечения относительно общего объема полезных площадей организации. Аналогичный расчет применительно к активной части ОС характеризует параметры обновления медицинской техники. За анализируемый период полезную информацию для руководителя организации представят показатели движения ОС: годовой прирост, коэффициенты обновления, выбытия, накопления, степень износа.

При оценке экономической результативности использования медицинской техники учитываются: фактическая нагрузка на апnаратуру, 
непрерывность ее работы с учетом коэффициента сменности (наиболее актуального для выполнения медицинских услуг с помощью высокотехнологичных дорогостоящих приборов). Возможности управления материально-техническими ресурсами повышаются при активном использовании информационных технологий, внедрении мониторинга ОС по состоянию их обновления и износа.

В целях безопасности изделий медицинского назначения и медицинской техники Правительством Российской Федерации утверждено положение о лицензировании деятельности по производству и техническому обслуживанию медицинской техники (за исключением случаев, когда техническое обслуживание осуществляется для обеспечения собственных нужд юридического лица или индивидуального предпринимателя). В этом документе озвучен термин «медицинская техника». Это - «медицинские изделия, представляющие собой инструменты, аппараты, приборы, оборудование, применяемые в медицинских целях отдельно или в сочетании, а также вместе с другими принадлежностями, необходимыми для применения указанных изделий по назначению, включая специальное программное обеспечение, и предназначенные производителем для профилактики, диагностики, лечения и медицинской реабилитации заболеваний, мониторинга состояния организма человека, проведения медицинских исследований, восстановления, замещения, изменения анатомической структуры или физиологических функций организма, предотвращения или прерывания беременности, функциональное назначение которых не реализуется путем фармакологического, иммунологического, генетического или метаболического воздействия на организм».

Лицензирование деятельности по производству и обслуживанию медицинской техники осуществляется Федеральной службой по надзору в сфере здравоохранения. В части производства медицинской техники в перечень работ и оказываемых услуг включены как само производство технических медицинских средств, так и - изготовление их по индивидуальным заказам по назначению медицинских работников и предназначенных для личного использования конкретным пациентом.

В части технического обслуживания - выполняемые работы предусматривают: монтаж и наладку техники; контроль ее технического состояния; периодическое и текущее техническое обслуживание, а также ремонт. Утверждены административный регламент по государственной 
регистрации медицинский изделий (2013 год) и государственная программа «Развитие фармацевтической и медицинской промышленности на 2013-2020 гг. с подпрограммой «Развитие производства медицинских изделий» по разработке и организации такого производства.

Анализ материально-технической базы, проведенный на основе единовременного учета основных фондов по всем типам медицинских организаций Российской Федерации, сотрудниками ЦНИИ организации и информатизации здравоохранения (1990 год) выявил, что половина из общей численности стационаров и треть поликлиник нуждались в капитальном ремонте и реконструкции, аварийными признаны 9,0\% больниц, почти 2,0\% амбулаторных организаций. Техническая оснащенность медицинской и специальной аппаратурой была невысокой, заметно отставая от развитых стран. Для исправления ситуации и с целью усиления государственного регулирования материально-технической базы системы здравоохранения были утверждены: приоритетный национальный проект «Здоровье»; программа модернизации здравоохранения (2011-2013 гг.). Предпринятые меры позволили к 2015 году обновить на $80 \%$ парк медицинского оборудования и техники в системе здравоохранения.

\section{Контродьные вопросы}

1. Сформулируйте значение термина «сеть медицинских организаций», перечислите условия ее формирования на российских территориях.

2. Каковы обобщенные требования к размещению типов медицинских организаций в зависимости от численности населения? Приведите примеры.

3. Дайте определение терминов «медицинские изделия», «медицинская техника». Где размещаются сведения о присвоении изделию вида номенклатурной классификации?

4. По каким показателям рассчитывается состав и структура основных средств? Дайте определение терминов «фондооснащенность», «фондовооруженность».

5. Назовите показатели, отражающие процесс использования основных фондов. За какой период, как правило, производится их расчет?

6. Что такое «износ», «амортизация» основных средств? Сформулируйте общность, различия. Как определяется степень износа?

7. Подлежит ли амортизации имущество бюджетных организаций?

8. Для каких целей и как распределяется амортизируемое имущество, каков диапазон сроков? 
9. Назовите показатели эмпирического определения величины износа и обновления по группам основных средств. Перечислите показатели их движения.

\section{Официальные документы, нормативно-правовые акты}

\section{Литература}

1. «Об утверждении Правил обязательного медицинского страхования»: Приказ Минздравсоцразвития от 28.02.2011 № 158н (в ред. от 11.01.2017, раздел 6).

2. «О требованиях к размещению медицинских организаций государственной системы здравоохранения и муниципальной системы здравоохранения исходя из потребностей населения»: Приказ Минздрава России от 27.02.2016 № 132н.

3. «Отраслевые особенности бюджетного учета в системе здравоохранения»: утверждены Минздравсоцразвития России от 09.06.2007.

4. «Об утверждении административного регламента федеральной службы по надзору в сфере здравоохранения по предоставлению государственной услуги по государственной регистрации медицинских изделий»: Приказ Минздрава России от 14.10.2013 №737н (ред. от 18.07.2016 № 521н).

5. «Об утверждении государственной программы Российской Федерации «Развитие фармацевтической и медицинской промышленности на 2013-2020 годы»: Постановление Правительства Российской Федерации от 15 апреля 2014 № 305 (ред. от 28.12.2017 № 1673).

6. Отраслевые и экономические показатели противотуберкулезной работы в 2016-2017 гг. Аналитический обзор основных показателей и статистические материалы / под ред. С.А. Стерликова. - М.: РИО ЦНИИОИЗ, 2018. - С. 76.

7. Райзберг Б.А., Лозовский Л.Ш., Стародубцева Е.Л. Современный экономический словарь. - М.: ИНФРА, 2007. - 495 с.

8. Стародубов В.И., Рогожников В.А., Пачин М.В. Особенности управления ресурсами здравоохранения в новых экономических условиях // Проблемы управления здравоохранением. - 2002. № 3. - C. $10-18$. 


\section{ГДава 3. ТЕХНИЧЕСКИЕ РЕСУРСЫ, МАТЕРИАЛЬНО-ТЕХНИЧЕСКИЙ МЕНЕДЖМЕНТ МЕДИЦИНСКИХ ОРГАНИЗАЦИЙ}

\section{1. Индикаторы состояния и исподьзования ресурсов медицинской организации}

Адекватная обеспеченность материально-технической базы медицинских организаций в значительной мере способствует выполнению диагностической и лечебной помощи в соответствии с современными клиническими рекомендациями, порядками и стандартами оказания медицинской помощи. Радикальное обновление материальных ресурсов, проведенное, с начала третьего тысячелетия в ходе последовательной реализации федеральных проектов в сфере здравоохранения, внесло свой существенный вклад в управление материальными запасами медицинских организаций, способствовало развитию и внедрению в их практическую деятельность актуальных приемов менеджмента, логистики, бизнес-планирования.

При проведении контроля качества и безопасности обращения медицинских изделий в процесс внутреннего и ведомственного аудита государственных медицинских организаций включены группы информативных показателей. Среди них - наличие приказов по хранению, учету, эксплуатации изделий, требующих периодических проверок, технического обслуживания, регистрации нежелательных реакций; регулярный внутренний контроль качества и безопасности обращения МИ; соблюдение правил эксплуатации изделий, наличие инструкций и обучение персонала при поступлении нового оборудования; профилактическое техническое обслуживание МИ; разработка алгоритма взаимодействия с территориальными органами Росздравнадзора.

Столь глубокая и подробная оценка необходима в связи с особенностями применения изделий в медицинских целях согласно установленному классу степени риска - низкая, средняя, повышенная, высокая. Необходимая информация для организации контроля и безопасности обращения МИ сгруппирована на сайте Федеральной службы по надзору в сфере здравоохранения.

Состояние материальной ресурсной базы медицинской организации (MO) анализируется по оценке базисного фонда в соответствии со следующими характеристиками:

- стоимость структурных компонентов основных фондов, дифференцированная с учетом коэффициентов (поправки на инфляционный 
процесс) по группам: здания и сооружения, оборудование, инструментарий, компьютерная техника, транспорт, инвентарь, хозяйственные средства - для определения обоснованности объема финансовых ресурсов на их содержание;

- доля изношенности фондов как фактор, способствующий уточнению мер по замене оборудования и техники;

- уровень и темп обновления фондов по установленным нормативно-практическим параметрам (глава 2), определяющие перспективы развития организации;

- долевое соотношение между активными и пассивными фондами медицинской организации;

- состав оборудования по годам его использования (в абсолютных числах и соответствующей доле каждого вида от общего числа в процентах);

- использование медицинской техники по объему и времени выполняемой работы (лучевые, лабораторные, эндоскопические, функциональные и другие исследования).

Финансовая составляющая основных фондов медицинской организации включает определение их первоначальной, восстановительной и остаточной стоимости. Первоначальная (полная) балансовая стоимость отражает объем стоимости основных средств с их перевозкой, монтажными и наладочно-технологическими работами. В бухгалтерском балансе учет ведется по среднегодовой первоначальной стоимости. При ее расчете суммируются - половина балансовой стоимости средств на начало (01.01.) отчетного года + половина балансовой стоимости на начало (01.01.) следующего за отчетным, года + полные балансовые помесячные стоимости средств с февраля по декабрь включительно за отчетный год.

Восстановительная стоимость определяется при аудите и переоценке фондов для установления степени износа медицинского оборудования. Остаточная стоимость вычисляется разностью между полной балансовой стоимостью и суммой износа основных фондов.

При эксплуатации фондов происходит постепенная потеря их технических и технологических характеристик, что с годами приводит к износу и утрате величины первоначальной стоимости за счет непосредственно материальных (физических) потерь. Величина материального износа ОС, оборудования устанавливается в виде коэффициента по соотношению фактического числа лет эксплуатации к их нормативному сроку применения (для оборудования и техники - указываемому в техническом паспорте), либо выражается в процентах. 
Моральный (функциональный) износ ОС характеризуется отклонением показателей эксплуатации фондов от уровня прогрессивных технических требований к их применению, свидетельствуя, с этих позиций, об устаревании основных активов.

В стоимостных единицах износ рассматривается как отражение процесса амортизации, при котором, за время эксплуатации основных фондов, часть, потраченных на них финансовых средств, переносится на стоимость оказываемой организацией медицинской помощи. Размеры амортизационных накоплений, соотнесенные к балансовой стоимости оборудования, определяют норму амортизационных отчислений (НАО) в процентах, рассчитываемую как:

$$
\mathrm{HAO}=(\text { СБ }- \text { СЛ }) /(\text { ТН } \times \text { СБ }) \times 100,
$$

где СБ - балансовая стоимость; СЛ - ликвидационная стоимость оборудования (при проведении работ по демонтажу); ТН - нормативный срок службы оборудования. В последнее десятилетие используется метод отчислений на амортизацию не по объектам, а на стоимость амортизационной группы (по сроку функционирования объекта). Однако скорость развития новых технологий (техники!) вынуждает обновлять фонды до истечения физического срока их службы. Приходится пересматривать состав групп, определять новые сроки полезного использования активов, что усложняет процесс расчетов и решение поставленных задач.

В повседневной экономической деятельности медицинской организации предусматриваются расчеты износа, амортизации, остаточной стоимости оборудования, которые используются как исходные данные с определением нормативного процента амортизации и расчетом ежегодной суммы амортизационных отчислений (сумма балансовой стоимости, умноженная на НАО).

Если износ и амортизация идентичны по темпам, то на практике величина, на которую произошел материальный и моральный износ, может не соответствовать накопленной сумме амортизации. Понятие «износ» используется, как правило, некоммерческими структурами, в их числе - медицинскими организациями системы Минздрава России. По своим объектам основных фондов они начисляют не амортизацию, а износ (линейным способом), отражая его за балансом, согласно правилам бухгалтерского учета (п. 17). 
Анализ рационирования ситуации по использованию основных фондов в медицинской организации проводят по расчетам таких же характеристик материально-технического состояния, как и по системе здравоохранения в целом: фондооснащенность, фондовооруженность, фондоотдача, фондоемкость.

Фондооснащенность, как индикатор обеспеченности основными фондами, отражает соотношение балансовой стоимости активной части ОС к единице мощности организации. Плановая мощность характеризуется: числом посещений в смену (поликлиника) как отражение типовой «пропускной» способности этой организации при соблюдении санитарных и эпидемиологических правил и требований; числом больничных коек (стационар).

Показатель предусматривается проектной документацией и имеет различную величину по типам организаций. При отсутствии таких документов верификация проводится расчетом величины, полученной от деления фактически занимаемой площади на ее нормативный показатель. Инструкция по определению плановой площади введена в практику давно в качестве критерия мощности амбулаторно-поликлинической организации (приказ Минздрава СССР от 20.07.1979 г. № 650). С учетом требуемой площади (в квадратных метрах) на одно посещение, определяется ее плановая величина в смену для диагностических, лечебных, профилактических подразделений, предоставляющих медицинскую помощь в амбулаторных условиях.

Помимо сравнения фактической и плановой мощностей, можно рассчитать показатель обеспеченности ими в расчете на 1000 (10 тыс.) прикрепленного населения с последующим отражением в процентах. Величина, составляющая менее $100 \%$, свидетельствует о недостатке необходимых размеров площадей. Плановая мощность поликлиники изменится, если в ходе капитального ремонта ее активные и вспомогательные размеры увеличились (появились новые подразделения на новых площадях) или уменьшилась (прежние отделения закрылись), либо используются организацией в других вариантах (аренда, технические, инженерные и иные цели). В расчеты не включаются коридоры, переходы, тамбуры.

Общая характеристика основных фондов стационара медицинской организации включает количество круглосуточных коек (на конец года), их среднегодовое число с расчетом показателя обеспеченности больничными койками (на 1000 населения). Использование коечного фонда 
отражают следующие показатели: среднее число занятости («работы») больничной койки в отчетном году, величина (объем) ее оборота, средняя длительность нахождения пациента на койке стационара. Эти показатели рассчитываются по стационару в целом, по клиническим отделениям и по профилю коек. В расчеты по использованию коечного фонда не включаются койки сестринского ухода, хосписные, геронтологические и для здоровых новорожденных в акушерских стационарах.

Фондовооруженность отражает техническую и технологическую обеспеченность профессиональной деятельности медицинских работников организации. Ее определяют соотношением балансовой стоимости $а \kappa-$ тивной части основных фондов к штатной численности медицинских работников организации, осуществляющих медицинскую деятельность (врачи и работники среднего звена). Штатная численность как более стабильный параметр, позволяет уточнить причины изменений показателя, происходящие по годам наблюдения. Динамика фондооснащенности и фондовооруженности может определяться ежегодно, но на практике рассчитывается через каждые три года.

Фондоотдача (соотношение доходов, полученных от деятельности медицинской организации к стоимости основных фондов) $и$ фондоемкость (соотношение стоимости ОС к полученным доходам) - показатели, косвенно свидетельствующие об уровне фондооснащенности и фондовооруженности медицинских организаций.

Для руководителя медицинской организации интересна и значима информация по динамическим сдвигам в структуре и стоимости основных фондов за годы деятельности МО, степень их изношенности, а также - обновления в сравнении с установленными темпами по группам OC (глава 2). Чтобы просчитывать и анализировать эти сведения, необходимы: учет активов по составу, структуре, состоянию, стоимости и характеру передвижения ОС организации, которые определяются при инвентаризации основных фондов.

Инвентаризация - основной способ фактического контроля по сохранности основных активов организаций. Процесс инвентаризации регламентирован статьями Федерального закона №402-Ф3 «О бухгалтерском учете», «Положением по ведению бухгалтерского учета и бухгалтерской отчетности (приказ Минфина России № 34н) и методическими указаниями по инвентаризации имущества и финансовых обязательств. Цель процедуры - выявление фактического наличия имущества; 
его сопоставления с данными бухгалтерского учета; проверка полноты отражения фактической ситуации в учетных документах.

Унифицированной формой первичной учетной документации является «Инвентаризационная опись основных средств (форма № ИНВ1 , в которой указывается их первоначальная стоимость) и сличительная ведомость по ОС - форма № ИНВ-18. Допускается учет ОС с использованием инвентарных карточек. Для объектов ОС (с 2018 года) указывается их состояние: «в эксплуатации», «требуется ремонт», «находится на консервации», «не соответствует требованиям эксплуатации», «не введен в эксплуатацию». Отражается целевая функция актива: введение в эксплуатацию», «ремонт», «консервация объекта», «дооснащение», «списание», «утилизация.

Кроме перечисленных расчетных целевых индикаторов оценки состояния материально-технической базы МО, можно детализировать информацию, используя данные медицинской статистики по годам работы МО, что представлено на примере табл. 8.

Таблица 8

Рост (снижение) числа развернутых для оказания медицинской помощи подразделений, отделов, отделений, кабинетов, абсолютные числа. Источник информации: форма ГСН № 30 (таблица 1001, гр. 1, стр. 01-140 за предыдущий период - таблица 1001, гр. 1, стр. 01-140 за настоящий период

Темп роста (снижения) числа развернутых для оказания медицинской помощи подразделений, отделов, отделений, кабинетов в \% к предыдущему периоду. Источник информации: форма ГСН № 30, таблица 1001, графа 1 за предыдущий период / гр. 1 за настоящий период × 100, стр. 1-140

\section{2. Оценка состояния медицинской техники и результативности ее исподьзования}

Оснащенность МО техникой (диагностическими и лечебными аппаратами, техническими комплексами, приборами) определяется в процессе сопоставления их фактических видов и количества единиц с рекомендуемыми стандартами оснащения поликлиник, оказывающих помощь в амбулаторных условиях, а также - по стандартам оснащения, рекомендованным порядками оказания профильной медицинской помощи в стационаре и поликлиническом отделении для прикрепленного населения. При проведении сравнения и выявлении отклонений 
от стандартов, намечаются мероприятия по их устранению для достижения требуемых критериев.

Наличие медицинской техники и ее состояние отражают правильное ведение учета, как объекта основных (активных) фондов. Учет проводится по инвентарной описи. В поликлиниках с невысокой плановой мощностью и врачебных амбулаториях учет аппаратов и приборов, как инвентарных объектов, открывается при заполнении карточек (ТЭП), формирующих картотеку с присвоением инвентарного номера. Ведение учета медицинской техники, как объекта ОС, от момента поступления в МО и регулярного контроля (ежегодно, либо однократно за трехгодичный период) позволяет определить:

1. Состав аппаратуры по годам ее использования (с расчетом доли каждого вида в общей численности).

2. Балансовую стоимость приборов (по годам их работы, объемам выполненных услуг) для каждого вида медицинской техники по системе бухгалтерского учета ОС.

3. Фактический срок окупаемости приборов, аппаратов, оборудования с учетом эмпирических нормативов технического износа, обновления $(15,0 \%)$, стоимости одного диагностического исследования, или лечебной процедуры в системе обязательного медицинского страхования.

Состояние оснащенности медицинской техникой по ее видам позволяет уточнить доступность медицинских технологий для территориального населения. Так, в целях диагностики определяется наличие: компьютерных, магнитно-резонансных томографов, маммографов, ультразвуковых сканеров, электроэнцефалографов и других аппаратов; в лечебных целях - установок для радиотерапии, физиотерапии и другой аппаратуры с идентификацией, как их общего числа, так - и количества, приходящегося на 10 тыс. проживающего населения.

Анализ экономической эффективности использования медицинской техники рассчитывается по методике, предложенной Л.М. Манукяном и В.Т. Вишняковым (1987) и, в адаптированном варианте, сохраняющей актуальность до настоящего времени при определении эффективности работы медицинского изделия как такового. Рассчитываются - коэффициент использования единицы техники, коэффициент сменяемости (сменности) фактический срок окупаемости медицинского изделия.

Определение возможного для выполнения количества исследований на единицу медицинской техники в год осуществляется на основе 
календарного фонда рабочего времени (в соответствии с режимом работы МО), уменьшенного на коэффициент простоя техники. В случае ремонта, либо времени сервисного обслуживания, он устанавливается в процентах (от 0,05 до 0,2) в зависимости от сложности оборудования.

Коэффициент использования единицы техники (календарного обслуживания) = числу дней ее возможного использования согласно режиму работы МО × на полное время дневной работы (по паспорту изделия) / число календарных дней в году.

Коэффициент сменяемости (сменности) = числу фактических часов работы медицинского изделия в году / число максимально возможных часов его работы (по паспортным данным) в году. Результативным можно считать использование техники в тех МО, где величина первого показателя не ниже 0,9, а второго - превышает 0,6. Адекватным признается применение в рабочем состоянии медицинских изделий в течение допустимо возможного периода времени.

Медицинская эффективность, отражающая доступность диагностической и лечебной помощи для населения, рассматривается с позиции нормативного годового количества исследований, приходящегося на единицу медицинской техники, умноженного на время выполнения каждого исследования. Нормативное время на одно исследование по видам изделий и оборудования отражено в соответствующих приказах Минздрава России (от 02.08.1991 № 132, 30.11.1993 № 283, 05.04.1996 № 128, 31.05.1996 № 222 и других).

\section{3. Управление материальными ресурсами медицинской организации}

Экономический эффект от использования техники и оборудования (в особенности высокотехнологичного и дорогостоящего) формируется при недопущении простоев в их работе. Причинами простоев, как показали исследования, в 80,0\% являются предотвратимые факторы: производственный брак и случайные поломки - 20,0\%, неправильная эксплуатация $-20,0 \%$, некачественное техническое обслуживание $-60,0 \%$. Из 20,0\% аппаратуры, которая простаивает, в 2/3 случаев выявлена неисправность, в остальных - передача в другие МО, консервация, подготовка помещения, списание, или - отсутствие введения техники в эксплуатацию.

Из других причин обнаруживается несоответствие помещений нормативным требованиям, длительный ремонт. Все эти факторы 
встречаются в практической деятельности, несмотря на созданную систему государственной регистрации и контроля за обращением медицинских изделий (более 20 нормативных актов). Поэтому в планах Росздравнадзора намечено внедрение инспектирования производственных площадок по их соответствию ГОСТ ИСО 12485-2011 с постепенным исключением устаревшей системы лицензирования.

Наличие в медицинских организациях современной техники, оборудования, медицинских изделий не является гарантом их рационального использования с улучшением доступности и качества диагностической, лечебной, реабилитационной, профилактической помощи. Работу на аппаратуре нового поколения может осуществлять специально подготовленный, квалифицированный врачебный и средний медицинский персонал при соблюдении технологий выполнения манипуляций и процедур, осуществлении контроля технического обслуживания приборов. При отсутствии этих условий нередок факт недоиспользования сложной медицинской техники и нерентабельность затрат на ее приобретение.

Экономическая эффективность использования техники и оборудования может быть получена в МО, способных в двухсменном режиме работы организовать оказание диагностической или лечебной помощи необходимому числу пациентов. Непрерывность работы техники нуждается в перманентном ведении контроля наличия материальных запасов (комплектующих средств) к приборам и оборудованию.

Для улучшения эффективности использования медицинских изделий с учетом затрат на их обслуживание и ремонт, территориальные органы управления здравоохранением способны, ориентируясь на уровень экономического развития федерального субъекта (при недостаточном его обеспечении), развивать механизмы взаимодействия с товаропроизводителями собственной и сопряженных территорий.

Так, при централизованных поставках материальных ресурсов, с учетом возможностей экономической базы субъекта, можно снизить логистические издержки при экономии бюджетных средств. С целью снижения экономических потерь, морального износа при современном ускорении темпов технического прогресса в практическую работу МО, подведомственных Минздраву России (преимущественно многопрофильные стационары, клинико-диагностические центры), для обеспечения нормативного объема работ, в штатное расписание вводятся должности инженеров по оборудованию либо по организации эксплуатации оборудования. 
Мероприятия облегчают своевременные пуско-наладочные работы, контроль и эксплуатацию медицинских изделий, периодическое и текущее профилактическое обслуживание, неотложный ремонт, обучение персонала, что в совокупности продлевает жизненный цикл изделия. Сохраняют актуальность контракты с сервисными организациями по медико-техническому гарантийному обслуживанию медицинской техники.

Процесс управления парком медицинских изделий в организациях всех уровней оказания медицинской помощи, включает принятие решений по обновлению активов. Для этого в МО необходимо:

1. Создание системы мониторинга с учетом количества (и доли) медицинских изделий: поступивших, эксплуатируемых, выработавших нормативные сроки. Ведение расчета доли отечественной и импортной медицинской техники. Контролирование данных бухгалтерской отчетности.

2. Изучение рынка медицинских изделий. Формирование закупочных планов-заданий.

3. Создание сервисной службы в МО третьего уровня для технического обслуживания и ремонта.

4. Выявление зон неэффективности использования активов с установлением причинно-следственных связей.

Правовыми основами материально-технического обеспечения МО являются стандарты оснащения диагностическим оборудованием; порядки медицинской помощи (по профилям оказания и разделу «оснащение»). Финансовыми основами, в условиях одноканального финансирования и переводе средств в обязательное медицинское страхование $(\mathrm{OMC})$, расширен перечень финансируемых через ОМС статей расходов, определены источники формирования нормированного страхового запаса территориальных фондов с конкретизацией расходования финансов.

Законодательно закреплена обязанность МО по направлению денежных средств на ремонт медицинских изделий. Организациям здравоохранения предоставлено право приобретения приборов, аппаратов с нормированной стоимостью, как возможность самостоятельного принятия решений по закупкам медицинской техники.

Наблюдения, проведенные в условиях стационаров разного уровня оказания помощи, свидетельствовали о неравномерности нагрузки по использованию медицинских изделий - к нормативу приближались лишь крупные городские больницы. В случаях недоиспользования медицинской техники увеличивался фактический срок окупаемости приборов и стоимость медицинских услуг за счет роста отчислений на износ, амортизацию. 
Центральные районные и районные больницы не выполняли необходимый объем исследований, его величина была меньше нормативной на 25$50,0 \%$, в связи с чем, срок окупаемости техники в организациях первого уровня оказания помощи удлинялся, способствуя ее моральному устареванию в условиях ускорения темпов технического прогресса.

Рассматривая вопросы менеджмента применительно к медицинской технике (в особенности, дорогостоящей) необходимо отметить, что экономическая результативность обеспечивается в МО, способных реализовать в двухсменном режиме работы оказание услуг расчетному количеству пациентов и имеющих необходимые штаты медицинских работников. Отсутствие специалистов для обеспечения нормативного объем работ, приводит к экономическим потерям.

\section{Контродьные вопросы}

1. Назовите основные показатели качества и безопасности медицинских изделий, исследуемые в ходе внутреннего и внешнего аудита медицинских организаций.

2. Перечислите характеристики, отражающие состояние материально-технической базы медицинской организации.

3. Сформулируйте финансовую составляющую основных фондов организации. Как проводится расчет показателей?

4. Каковы приемы определения величины материального износа основных средств, оборудования, медицинской техники, что понимают под моральным износом?

5. Объясните, как рассчитывается норматив и сумма амортизационных отчислений (по объектам? по группам?).

6. Перечислите и охарактеризуйте основные показатели, отражающие состояние материальных ресурсов медицинской организации.

7. Дайте определение термина «плановая мощность». Поясните смысл термина. Как можно произвести расчет показателя при отсутствии проектной документации?

8. Назовите основной способ контроля по сохранности основных фондов каждой организации. Какие основные нормативные акты его регламентируют? Перечислите унифицированные формы учета.

9. По каким критериям осуществляется оценка наличия и состояния медицинской техники?

10. Какие показатели используются для определения результативности использования медицинской техники? Назовите формулы их расчета. 
11. Перечислите предотвратимые причины простоя техники и оборудования в медицинской организации.

12. Какие действия могут улучшить процесс управления состоянием и использованием медицинской техники в каждой организации.

\section{Официальные документы, нормативно-правовые акты}

\section{Литература}

1. «Об утверждении номенклатурной классификации медицинских изделий»: Приказ Минздрава России от 06.06.2012 №4н (в ред. от 25.09.2014).

2. «О присвоении вида номенклатурной классификации медицинских изделий»: письмо Федеральной службы по надзору в сфере здравоохранения от 28.11.2016 № 01И-2375/16.

3. Об утверждении Положения по бухгалтерскому учету «Учет основных средств» ПБУ6/01»: Приказ Минфина России от 30.03.2001 № 26н (в ред. от 16.05.2016).

4. «Об утверждении стандарта бухгалтерского учета для организаций государственного сектора «Основные средства»: Приказ Минфина России от 31.12.2016 № 257н.

5. Вишняков В.Т., Манукян Л.М. О методологии анализа использования дорогостоящего оборудования // Экономика здравоохранения. 1999. № 4. С. 14-15.

6. Владзимирский А. Телерадиология позволяет оптимизировать работу диагностической службы // Здравоохранение. 2017. № 5. С. 108-112.

7. Засимова Л.С. Внедрение новых технологий в медицинских организациях: Зарубежный опыт и российская практика. Государственный университет - Высшая школа экономики (ГУ ВШЭ). 2013. 272 с.

8. Кадыров Ф.Н. Методы оценки эффективности деятельности медицинских учреждений. М.: ИД «Менеджер здравоохранения»,2011. 496 с.

9. Лантух 3. Как избежать штрафов за простой оборудования // Здравоохранение. 2017. № 6. С. 54-59.

10. Рааб М. Технологический менеджмент в области здравоохранения. Стратегия и экономика оснащения ЛПУ / М. Рааб, Ф.Н. Кадыров, А.Ю. Исаков. М.: Грантъ, 2003. 248 с.

11. Рожков Б. как избежать ошибок при покупке медоборудования // Здравоохранение. 2017. № 12. С. 102-105.

12. WHO Global Model Regulatory Framework for Medical Devices including in vitro diagnostic medical devices. WHO Medical device technical series. 2017. S. 76. Документационный центр ВОЗ. 


\section{Глава 4. ОСНОВЫ ПАСПОРТИЗАЦИИ МЕДИЦИНСКИХ ОРГАНИЗАЦИЙ, МЕДИЦИНСКАЯ СТАТИСТИКА МАТЕРИАЯЬНЫХ И ТЕХНИЧЕСКИХ РЕСУРСОВ}

\section{1. Роль паспортизации медицинских организаций в управлении материальными ресурсами}

Рассматривая основные позиции по управлению материальными ресурсами медицинских организаций, необходимо отметить необходимость наличия программных информационных средств, с помощью которых как создается материальная база данных, так и поддерживается в процессе эксплуатации. Технологии, ориентированные на обработку и передачу информации с помощью компьютерной базы, включают, прежде всего: систему учета и средства контроля по инвентаризации используемой полезной площади; повышение занятости и оборота площадей; регистрацию прав на объекты недвижимости, в том числе - земельные; меры по ремонту и содержанию имущества; сокращение доли потребления коммунальных услуг.

Вопросы ведения и регламентирования учета ОС нацелены, преимущественно, на выявление нецелевого финансирования, контролирование постановки на учет комплектов конструктивно-сопряженных элементов, ведения процедур списания объектов ОС. К средствам, которые оказывают помощь по устранению возникающих проблем, относят создание системы паспортизации медицинских организаций. Система предусматривает координацию действий в конкретных направлениях (табл. 9).

Таблица 9

\section{Направления паспортизации медицинских организаций}

\begin{tabular}{l} 
1. Формирование единой нормативной базы по составу параметров электрон- \\
ного паспорта \\
\hline 2. Создание единого реестра оснащенности медицинскими изделиями \\
\hline 3. Интеграция с используемыми системами материального учета \\
\hline 4. Сопряженность паспорта с номенклатурой медицинских услуг \\
\hline $\begin{array}{l}\text { 5. Объединение с правилами земельного учета территории (геодезические по- } \\
\text { досновы) }\end{array}$ \\
\hline
\end{tabular}




\section{Н.В. Данилова}

Источниками для создания паспорта МО и его обеспечения являются основные документы: ГОСТ Р-52978-2008 по вопросам информатизации здоровья и составу данных о медицинской организации для электронного обмена информацией; разработки в области учета зданий и сооружений; системы материального учета; системы учета федерального имущества - единый государственный реестр юридических лиц и индивидуальных предпринимателей (ЕГРЮЛ/ИП). В задачи паспортизации входит, прежде всего, формирование данных о медицинской организации (табл. 10).

Таблица 10

\section{Сведения о медицинской организации}

1. Реестр лицензий

2. Идентификационные (банковские) и справочные характеристики

3. Сведения о территории обслуживания

4. Параметры организационной и штатной структуры

5. Кадровый состав

6. Характеристики коечного фонда

7. Показатели материально-технического оснащения

8. Государственное (муниципальное) задание на предоставление организацией медицинской помощи

Типовые разделы паспорта включают: параметры общих и административных сведений; условия размещения и лечения; площади и здания; организационную структуру, кадровый состав, оснащение организации (табл. 11).

Сведения о регистрации паспортных данных МО, отражают ряд значимых разделов. Среди них - площади и здания (площадка, занимаемая организацией, связь с транспортными узлами, здание); оснащение МО - медицинское оборудование, транспортные средства, информационные системы, а также - медицинская техника (реестр МИ, карты МИ, классификаторы, в том числе общероссийские, регистрационные удостоверения МИ). 
Таблица 11

\section{Структурные компоненты паспортизации МО}

\begin{tabular}{|l|l|l|l|}
\hline Общие сведения & $\begin{array}{l}\text { Административные } \\
\text { данные }\end{array}$ & $\begin{array}{l}\text { Условия размеще- } \\
\text { ния и лечения }\end{array}$ & $\begin{array}{l}\text { Организацион- } \\
\text { ная и кадровая } \\
\text { структура }\end{array}$ \\
\hline $\begin{array}{l}\text { Классификаци- } \\
\text { онная структура }\end{array}$ & $\begin{array}{l}\text { Банковские рекви- } \\
\text { зиты }\end{array}$ & $\begin{array}{l}\text { Объекты инфра- } \\
\text { структуры }\end{array}$ & $\begin{array}{l}\text { Штаты } \\
\text { Подразделения }\end{array}$ \\
\hline $\begin{array}{l}\text { Регистрацион- } \\
\text { ные данные }\end{array}$ & $\begin{array}{l}\text { Лицензии (сер- } \\
\text { тификаты) на вид } \\
\text { деятельности, право } \\
\text { пользования недрами }\end{array}$ & $\begin{array}{l}\text { Медицинские ус- } \\
\text { луги, технологии } \\
\text { Питание паци- } \\
\text { ентов }\end{array}$ & $\begin{array}{l}\text { Кадровый состав } \\
\text { Медицинские } \\
\text { работники и их } \\
\text { профиль }\end{array}$ \\
\hline $\begin{array}{l}\text { Адресные све- } \\
\text { дения }\end{array}$ & $\begin{array}{l}\text { Обслуживаемое на- } \\
\text { селение }\end{array}$ & $\begin{array}{l}\text { Специализация } \\
\text { МО } \\
\text { Природные лечеб- } \\
\text { ные факторы }\end{array}$ & $\begin{array}{l}\text { Личные данные, } \\
\text { должностные, } \\
\text { профессиональ- } \\
\text { ные }\end{array}$ \\
\hline
\end{tabular}

Необходимо знание свода правил (СП), который устанавливает технологические, технические, санитарно-эпидемиологические и эргономические требования и распространяется на проектирование новых, реконструируемых, капитально ремонтируемых зданий МО.

Данные ведения бухгалтерского учета в МО представлены показателями объема остаточной стоимости, техническим состоянием изделий и средствами их измерения, регистрацией расходных материалов.

Состояние информатизации отражается в количестве единиц электронно-вычислительной техники, наличии выхода в Интернет, электронной почты, электронной записи на врачебный прием, электронных карт пациентов и электронных рецептов. Актуализируется значимость использования мобильных (m-health) технологий для диагностики неотложных состояний, контроля функционирования внутренних органов пациента, организма в целом с возможностью дистанционного внесения в лечебный процесс необходимых корректив.

Информационно-аналитическая система (ИАС) Минздрава России начала разрабатывать программный комплекс по ведению паспортов МО РФ с 2013 года. В настоящее время программа ИАС к применению в практике территориального и федерального здравоохранения 
подготовлена, что позволяет улучшить учет, движение, состояние активов в МО, продлевая их жизненный цикл.

Для оптимизации территориального планирования медицинской инфраструктуры в 2016 году были пересмотрены и утверждены требования к размещению МО и подразделений МО, оказывающих первичную медико-санитарную помощь. Рекомендации базируются теперь не только на численности проживающего населения, но и на расстоянии до ближайшей медицинской организации с учетом нормативно закрепленного времени ожидания разных видов медицинской помощи. Для этого Минздравом России сформирована геоинформационная система, с помощью которой можно выявлять и точечно устранять риски снижения доступности в получении медицинских услуг.

\section{2. Статистика материально-технической обеспеченности системы здравоохранения}

Для органов здравоохранения и медицинских организаций разработаны единые формы статистической отчетности, утвержденные Федеральной службой государственной статистики (Росстат), формы учета и инструкции по их заполнению. Учет и отчетность позволяют реализовать требования к медицинской статистике - обобщение в государственном масштабе статистических данных по здравоохранению, анализ и сравнение результатов по городам, городским и сельским поселениям, федеральным субъектам и округам, Российской Федерации в целом.

Эти статистические материалы формируются на основании сводных данных годовой отчетности каждой медицинской организации, предоставляющей сумму сведений об объемах и характере деятельности, условиях ее реализации. Основой отчетности, обеспечивающей достоверность цифровых показателей, является учет, проводимый по единым формам и правилам (инструкциям), позволяющий выявлять достижения и недостатки в работе медицинской организации. Основные формы медицинской учетной документации включают журналы, медицинские карты, ведомости, выписки, отчеты, талоны и другую документацию, используемую в стационарах, поликлиниках, других типах организаций. К сожалению, некоторые документы не имеют официального статуса, либо перегружены информацией.

Статистическая отчетность, которая отражает количественные характеристики процессов, происходящих с материальными и техническими 
ресурсами в системе здравоохранения, представлена в сводных годовых отчетах по формам статистического наблюдения - № 30 «Сведения о медицинской организации» и № 47 «Сведения о сети и деятельности медицинских организаций». Федеральные субъекты предоставляют годовые отчеты Минздраву России и территориальному органу Росстата для формирования сводных таблиц по форме № 1-здрав «Сведения об организации, оказывающей услуги по медицинской помощи».

Данные, содержащиеся в этих статистических формах за годы, прошедшие с начала третьего тысячелетия, несколько раз обновлялись, дополняясь новыми сведениями, отражающими современные проблемы ресурсного обеспечения. Наряду с положительной направленностью освобождения от устаревших позиций, внесенные преобразования нередко приводят к затруднениям в получении и трактовке ряда аналитических данных, по годам статистического наблюдения, в связи с образованием новых динамических рядов и, следовательно - разрывом их непрерывности во времени и пространстве.

Порядок составления сводных годовых статистических форм № 30, № 47 руководствуется нормативно-правовыми актами (приказы Росстата, Минздрава России) и включает сведения по всем медицинским организациям подчинения Минздрава России на федеральном, субъектовом, муниципальном уровне. Эти формы предоставляются всеми медицинскими организациями (юридическими лицами), входящими в утвержденную отечественную номенклатуру. Ежегодно указывается суммарное число организаций с выделением расположенных в сельских поселениях и сельских населенных пунктах, входящих в состав городских округов.

В таблицах этих отчетных форм содержатся сведения, отражающие состояние инфраструктуры организаций. Так, указывается плановая (проектная) мощность организаций, оказывающих помощь в амбулаторных условиях, выраженная числом посещений в смену. Проектная мощность определяется на этапе проектирования, строительства и ввода в строй поликлиник, амбулаторий, центров, указывая на их пропускную способность. Основанием для заполнения этого раздела является паспорт организации, где указана проектная и рабочая площадь здания и кабинетов в квадратных метрах. Для организаций, построенных по типовым проектам, в которых указана проектная мощность в смену, плановая мощность принимается равной проектной. 
При отсутствии проектной документации плановую мощность можно определить расчетным путем: для самостоятельных организаций, работающих в амбулаторных условиях, либо входящих в состав других, но размещенных автономно, плановая мощность определяется как частное от деления их фактически занимаемой площади на нормативный показатель; при размешении поликлиники, входящей в состав организации и размещении с ней в одном комплексе, площадь, которую она занимает, следует увеличить за счет части площади общих кабинетов и вспомогательных служб суммарный показатель делится на нормативную величину.

Нормативы расчетных размеров площадей по типам медицинских организаций указаны в ведомственном приказе, утвержденном до 2000 года, но - действующим и актуальным и в настоящий период времени - Приказ Минздрава СССР от 20 июня 1979 г. № 650 «О введении показателя «Мощность амбулаторно-поликлинических учреждений» в практику планирования здравоохранения» (приложение 1). Рабочая величина площади включает сумму всех, занимаемых поликлиникой площадей, за исключением коридоров, тамбуров, переходов и занятых инженерными сетями и оборудованием.

Плановая мощность медицинской организации, оказывающей помощь населению в амбулаторных условиях, изменяется при открытии подразделений на новых площадях, в ходе капитального ремонта, когда имеющийся объем увеличился или уменьшился, либо выведен из подчинения поликлиники на другие цели (инженерные, аптечные, для аренды и пр.).

Нормативные показатели для определения мощности учреждений, оказывающих услуги по медицинской помощи населению приведены в форме статистического наблюдения № 1-здрав (2009) (табл. 12).

В формы № № 30,47 включены первичные статистические данные, показывающие сведения по состоянию инфраструктуры системы здравоохранения в организациях, оказывающих помощь в стационарных, амбулаторных условиях, диспансерах, станциями скорой помощи, центрами, санаторно-курортными и организациями особого типа, дневными стационарами, филиалами организаций. Показываются сведения о коечном фонде на конец отчетного года по их профилям, числе среднегодовых больничных коек. Перечисляются отделы, отделения, кабинеты, в том числе, предоставляющие высокотехнологичную помощь. Форма № 30 содержит также количественные показатели наличия в организациях диагностической и лечебной медицинской техники, оборудования с уточнением срока их эксплуатации. Указывается рентгенологическая - диагностическая 
и терапевтическая аппаратура, эндоскопическое и лабораторное оборудование, медицинская техника для функциональной диагностики. Выделяется компьютерное оборудование на базе процессоров с указанием видов операционных систем, серверов, мобильной аппаратуры (приложение 2).

Таблица 12

Нормативы для определения мощности организаций, оказывающих услуги по медицинской помощи населению

\begin{tabular}{|l|c|c|}
\hline \multirow{2}{*}{ Тип медицинской организаций } & \multicolumn{2}{|c|}{$\begin{array}{c}\text { Размер площади (кв. м) на одно } \\
\text { посещение в смену }\end{array}$} \\
\cline { 2 - 3 } & $\begin{array}{c}\text { Для авто- } \\
\text { номных } \\
\text { организаций }\end{array}$ & $\begin{array}{c}\text { Для организаций, } \\
\text { расположенных } \\
\text { в комплексе } \\
\text { с другими }\end{array}$ \\
\hline $\begin{array}{l}\text { Организации специализированной помощи: } \\
\text { Стоматологическая }\end{array}$ & 2,7 & 2,7 \\
\hline женская консультация & 6,3 & 4,4 \\
\hline Наркологическая & 5,3 & 3,8 \\
\hline Косметологическая & 5,2 & 5,0 \\
\hline врачебно-физкультурная & 13,2 & 13,2 \\
\hline $\begin{array}{l}\text { Организации, оказывающие различные } \\
\text { виды услуг }\end{array}$ & 6,8 & 4,6 \\
\hline
\end{tabular}

Показывается также техническое состояние зданий по типам медицинских организаций с его уточнением (требуют капремонта, реконструкции, аварийное состояние) и критериям индикаторов благоустройства (водопровод, горячее водоснабжение, центральное отопление, канализация, автономное энергоснабжение). Включаются сведения о медицинской деятельности, реализуемой с помощью материальных ресурсов - общее количество, сделанных пациентами к врачам посещений на амбулаторном приеме и на дому, число поступивших пациентов (взрослых и детей) и проведенных койко-днях в стационарных условиях.

Государственные (муниципальные), включая медицинские организации, составляют и представляют в территориальные органы статистики сведения о наличии и движении у них основных средств. Приказом Росстата от 19.07.2018 № 449 утверждены актуализированные отчетные годовые 
формы (4), начиная с 2018 года с указаниями по их заполнению - форма 11 «Сведения о наличии и движении основных фондов (средств) и других нефинансовых активов»; форма 11 (краткая) «Сведения о наличии и движении основных фондов (средств) некоммерческих организаций»; форма 11 (сделка) «Сведения о сделках с основными фондами на вторичном рынке и сдаче их в аренду»; форма 11-ФСС «Сведения о сроках службы объектов основных фондов». Форма 11 государственными медицинскими организациями не заполняется. Форма 11 (сделка) в случае отсутствия таких событий, как: реализация и приобретение в отчетном году бывших в эксплуатации объектов материальных основных фондов или наличия в отчетном году взятых в аренду и сданных в аренду объектов - не заполняется.

Форма 11ФСС заполняется только при наличии такого события как ликвидация объектов основных фондов, осуществленного за последние три года, либо планируемого к осуществлению в году, следующим за отчетным. Медицинские организации заполняют форму 11 (краткая) согласно форме и указаниям, приведенным в приказе Росстата.

С 2017 года Минздравом России предложен новый метод управления ресурсами медицинской организации. Актуальный, для российского здравоохранения, тренд опробован на практике и получил одобрение в международной системе оказания медицинской помощи в качестве Lean-менеджмента (бережливые технологии).

В основу принципов управления положены:

1. Учет потерь, к которым в медицине относятся все процедуры, не оказывающие пользу пациенту.

2. Оптимизация работы медицинской организации, требующая анализа текущего состояния процесса оказания помощи.

3. Устранение (либо минимизация) потерь с определением этапа, на котором они происходят.

Анализ текущего состояния процесса оказания медицинской помощи проводится с позиции: оснашения необходимым оборудованием для выполнения диагностических (лечебных) процедур; наличия компетенций у медицинского персонала для работы на современных аппаратах и приборах; определения функциональной нагрузки на врача, медицинскую сестру с учетом сменности работы; уточнения возможностей расширения лечебно-диагностических отделений. Текущее состояние оценивается с учетом перспектив развития, учета потерь на этапах ведения процесса и планирования задач по их устранению.

Планирование строится в соответствии с обеспеченностью ресурсами материальные, кадровые, технологические, финансовые, нематериальные 
(знания, умения, интеллект). Учитываются, в том числе, мотивационные факторы. Ресурсная матрица включает их текущую оценку (высокая, средняя, низкая), которая сопоставляется с прогнозируемым результатом и конкретными действиями по достижению планируемых мер (увеличить, сохранить, уменьшить). Синхронно проводится LEAN-анализ по причинным факторам выявленных потерь (перегрузки; простаивание; лишние процедуры; лишние запасы; ненужные перемещения; неполное использование ресурсов и др.). Основными условиями управления медицинской организацией (отделением) по методу бережливого производства (lean production) и его внедрения является соблюдение ряда правил: всегда помнить о пациенте, главный актив организации - люди (медицинские и прочие работники), непрерывно совершенствовать производственную деятельность, решать проблемы на рабочем месте.

В 2017 году Центр мониторинга и клинико-экономической экспертизы Росздравнадзора разработал предложения для организации внутреннего контроля качества и безопасности медицинской деятельности в рамках проекта Минздрава России «Бережливая поликлиника». В базовый перечень по качеству и безопасности вошли направления, большинство из которых тесно связаны с материальными и техническими ресурсами поликлиники:

1. Организация работы регистратуры.

2. Организация работы дневного стационара, стационара на дому.

3. Диспансеризация прикрепленного населения, диспансерное наблюдение за хроническими больными.

4. Организация профилактической работы, формирование здорового образа жизни среди населения.

5. Управление медицинскими кадрами, персоналом. Компетентность и компетенции.

6. Идентификация личности пациента.

7. Эпидемиологическая безопасность, профилактика инфекций, связанных с оказанием медицинской помощи.

8. Лекарственная безопасность, фармакологический надзор.

9. Контроль качества и безопасности медицинских изделий.

10. Организация экстренной и неотложной помощи. Хирургическая безопасность, профилактика рисков, связанных с оперативными вмешательствами.

11. Преемственность с другими медицинскими организациями. Передача ответственности за пациента.

12. Безопасность среды, организация ухода, патронажа пациентов, профилактики. 
13. Организация оказания медицинской помощи на основе данных доказательной медицины, в соответствии со стандартами, клиническими рекомендациями (протоколами лечения).

По каждому разделу работы разработаны группы качественных критериев («да» - выполнение; «нет» - неисполнение, неправильное исполнение). Дается оценка каждому разделу работы, затем - общая оценка. Оценка - выше $80 \%$ свидетельствует об эффективности и безопасности работы; 70-80\% по каждому из разделов - система в целом эффективна, но требует корректировки по отдельным разделам; уровень менее $70 \%$ отсутствует эффективность, нарушения имеются по многим разделам работы и требуют существенных изменений.

Все перечисленные критерии оценки имеют непосредственное отношение к использованию оборудования, медицинской техники по определению: потерь - времени, передвижения персонала, рисков - дефекты, медицинские технические и технологические ошибки, дублированию диагностических процедур. Их устранение позволяет достичь соответствия системе менеджмента качества (на основе ISO 9001:2008 - ГОСТ Р ИСО 9001-2008 и новой версии - стандарт ИСО-9001 2015 года) т. е. при переходе на международные и отечественные стандарты.

\section{Контродьные вопросы}

1. Какие цели в управлении состоянием обеспеченности материально-техническими ресурсами помогает решать паспортизация медицинских организаций?

2. Перечислите основные положения паспортизации медицинских организаций

3. Назовите типовые разделы паспорта организации.

4. Какие регистрационные данные состояния материально-технической базы содержит паспорт медицинской организации?

5. Какая ведомственная программа включает данные паспортизации входящих в регистр организаций?

6. Назовите статистические отчетные формы, отражающие состояние и изменения в материально-техническом обеспечении.

По каким причинным факторам ведется аудит состояния технического оснащения в соответствии с требованиями «бережливой поликлиники»?

7. Назовите положения внутреннего контроля качества и безопасности, предложенные Росздравнадзором, применительно к материальному и техническому обеспечению медицинских организаций. 


\section{Официальные документы, нормативно-правовые акты}

\section{Литература}

1. «Об утверждении статистического инструментария для организации Министерством здравоохранения Российской Федерации федерального статистического наблюдения в сфере охраны здоровья»: Приказ Росстата от 03.08.2018 № 483 (в ред. от 01.10.2018).

2. «Об утверждении форм федерального статистического наблюдения с указаниями по их заполнению для организации Министерством здравоохранения Российской Федерации федерального статистического наблюдения в сфере охраны здоровья»: Приказ Росстата от 24.12.2018 № 773.

3. «Федеральный стандарт бухгалтерского учета для организаций государственного сектора «Основные средства»: Приказ Минфина России от 31.12.2016 № 257 $\mathrm{H}$.

4. «Об утверждении статистического инструментария для организации федерального статистического наблюдения за деятельностью в сфере здравоохранения, травматизмом на производстве и естественным движением населения»: Приказ Федеральной службы государственной статистики от 07 августа 2009 г. № 163.

5. «Об утверждении статистического инструментария для организации федерального статистического наблюдения за наличием и движением основных фондов (средств) и других нефинансовых активов»: Приказ Росстата от 19.07.2018 № 449 (ред. от 31.08.2018)

6. «Об утверждении изменения № 1 к СП (своду правил) 158.13330.2014 Здания и помещения медицинских организаций. Правила проектирования»: Приказ Минстроя России от 16.12.2016 №977/пр. // СПС КонсультантПлюс.

7. Зуенкова Ю., Панина Е., Петрушевский А. Новый метод управления ресурсами медорганизации. LEAN-менеджмент // Здравоохранение. 2017. № 5. С. 84-90.

8. Иванов И. Внутренний контроль качества и безопасности в поликлинике // Здравоохранение. 2017. № 12. С. 26-35.

9. Обухова Т. Статистические формы по основным фондам: что изменилось? // Учреждения здравоохранения: бухгалтерский учет и налогообложение. 2018. № 9. С. 5-8.

10. Галионцева М. Техническое обслуживание медизделий. Пять советов, чтобы избежать претензий контролеров // Здравоохранение. 2018. №3. С. 96-102. 


\section{ЗАКЛЮЧЕНИЕ}

Система здравоохранения располагает всеми известными видами ресурсов - трудовыми, материальными, финансовыми, технологическими, интеллектуальными, информационными. Каждый из этих видов является значимым и необходимым при изучении текущего состояния и функционирования медицинских служб и организаций, участвующих в охране, восстановлении и поддержании здоровья населения страны, а также - в уточнении оптимальных тенденций, целей и стратегий их развития.

Наряду с традиционными показателями, характеризующими удовлетворение потребностей населения при оказании медицинской помощи и отражающими отзывчивость системы здравоохранения к нуждаемости жителей в адекватности объемов финансирования системы, обеспеченности кадрами врачей и медицинских сестер, актуализируется роль материально-технических ресурсов. Данный вид системного обеспечения можно рассматривать в качестве понятия из теории производственных функций - материализованный (овеществленный) технический прогресс (embodied technical progress). На практике он воплощается в новой технике, обновлении производственных материальных ресурсов, дополняя модель ресурсного обеспечения системы здравоохранения в целом.

Интеграция России в мировую экономическую систему, формирование новых производственных отношений изменили характер и направления деятельности различных секторов экономики, в том числе - здравоохранения. Решение важнейшей социальной задачи выполнение программы государственных гарантий по обеспечению населения медицинской помощью надлежащего объема и качества способствовали в новом тысячелетии постановке и последовательному решению ряда задач, включая укрепление инфраструктуры здравоохранения в соответствии с численностью, составом населения, структурой заболеваемости и смертности.

Приоритетной мерой развития материально-технической базы здравоохранения стали создание и регламентация работы сети межмуниципальных медицинских центров с концентрацией в них профильных и специализированных видов помощи, материальных, технических 
ресурсов в соответствии с порядками оказания медицинской помощи и построения ее по трехуровневому принципу.

Внедрение более совершенных форм и методов работы в здравоохранении и на уровне медицинских организаций, их контроль способствовали улучшению системы учета состава, численности и движения основных средств (фондов), расчетов амортизации, определению показателей обновления и износа основных фондов, фондовооснащенности и фондовоореженности медицинских работников. Регулярность проведения анализа и аудита структуры основных средств материально-технических средств по их первоначальной и остаточной стоимости позволяет верифицировать состояние материально-технической базы каждой медицинской организации, дать оценку оснащенности фондами системы здравоохранения в целом и по состоянию их отдельных компонентов.

Сравнение критериев состояния основных средств в динамике за годы наблюдения позволяет охарактеризовать уровень материально-технического обеспечения медицинских работников (врачебного и среднего персонала), определяющего доступность и качество оказания медицинской помощи. 


\section{ПРИЯОЖЕНИЯ}

Приложение 1

Нормативные показатели площадей для определения плановой мощности организаций здравоохранения, оказывающих населению медицинскую помощь в амбулаторных условиях

\begin{tabular}{|c|c|c|c|}
\hline \multirow[b]{2}{*}{$\begin{array}{l}\text { № } \\
\Pi / \Pi\end{array}$} & \multirow[b]{2}{*}{ Тип организации } & \multicolumn{2}{|c|}{$\begin{array}{c}\text { Размер площади (кв. м) } \\
\text { на одно посещение для } \\
\text { организаций: }\end{array}$} \\
\hline & & $\begin{array}{c}\text { вхо- } \\
\text { дящих } \\
\text { в состав } \\
\text { других }\end{array}$ & $\begin{array}{c}\text { самостоя- } \\
\text { тельных, рас- } \\
\text { положенных } \\
\text { автономно }\end{array}$ \\
\hline 1 & 2 & 3 & 4 \\
\hline 1. & $\begin{array}{l}\text { Поликлиника областной, краевой, республи- } \\
\text { канской больницы }\end{array}$ & 7,2 & 8,6 \\
\hline 2. & $\begin{array}{l}\text { Поликлиника детской областной, краевой, } \\
\text { республиканской б-цы }\end{array}$ & 7,6 & 10,9 \\
\hline 3. & Городская поликлиника & 4,6 & 6,8 \\
\hline 4. & Детская поликлиника & 7,6 & 10,9 \\
\hline 5. & Центральная районная (районная) поликлиника & 3,2 & 5,2 \\
\hline 6. & Амбулатория врачебная & & 5,4 \\
\hline 7. & Женская консультация & 4,4 & 6,3 \\
\hline 8. & Диспансеры: & & \\
\hline 9. & врачебно-физкультурный & & 13,2 \\
\hline 10. & кожно-венерологический & 2,4 & 3,4 \\
\hline 11 & наркологический & 3,8 & 5,3 \\
\hline 12. & онкологический & 6,2 & 9,2 \\
\hline 13. & противотуберкулезный & 3,6 & 4,7 \\
\hline 14. & психоневрологический & 3,8 & 5,3 \\
\hline 15. & Поликлиника госпиталя для ветеранов войн & 4,6 & 6,8 \\
\hline 16. & $\begin{array}{l}\text { Поликлиническое отделение специализирован- } \\
\text { ной б-цы: }\end{array}$ & & \\
\hline 17. & психиатрической больницы & 3,8 & 5,3 \\
\hline 18. & туберкулезная больница & 3,6 & 4,7 \\
\hline 19. & оториноларингологическая б-ца & 2,2 & 3,6 \\
\hline 20. & офтальмологическая б-ца & 2,2 & 3,6 \\
\hline 21. & физиотерапевтическая б-ца (поликлиника) & 5,0 & 5,2 \\
\hline
\end{tabular}


Приложение 2

Основные показатели состояния материально-технических ресурсов

\begin{tabular}{|c|c|}
\hline \multicolumn{2}{|l|}{ Показатели сети медицинских организаций } \\
\hline \multicolumn{2}{|l|}{ Медицинская помощь в стационарных условиях } \\
\hline Показатели & Формы ГСН \\
\hline Число больниц по типам организаций & \multirow{4}{*}{ Форма № 47} \\
\hline Число детских больниц & \\
\hline Число дневных стационаров в стационарных условиях & \\
\hline Число санаторно-курортных организаций & \\
\hline \multicolumn{2}{|l|}{ Медицинская помощь в амбулаторных условиях } \\
\hline Число самостоятельных поликлиник, расположенных автономно & \multirow{4}{*}{ Форма № 47} \\
\hline Число поликлиник, входящих в состав больниц & \\
\hline Число самостоятельных детских поликлиник & \\
\hline Число диспансеров (без стационаров) & \\
\hline Число дневных стационаров в амбулаторных условиях & Форма $14-$ дс \\
\hline \multicolumn{2}{|l|}{ Скорая медицинская помощь } \\
\hline Число станций скорой помощи & Форма № 30 \\
\hline \multicolumn{2}{|l|}{ Показатели мощностей медицинских организаций } \\
\hline \multicolumn{2}{|l|}{ Медицинская помощь в стационарных условиях } \\
\hline Количество больничных коек (всего) & \multirow{3}{*}{$\begin{array}{l}\text { Форма № } 47 \\
\text { № } 30, \text { № } 14\end{array}$} \\
\hline Обеспеченность койками на 10000 населения & \\
\hline Число коек в дневных стационарах в стационарных условиях & \\
\hline \multicolumn{2}{|l|}{ Медицинская помощь в амбулаторных условиях } \\
\hline Мощность самостоятельных поликлиник (всего) & \multirow{3}{*}{$\begin{array}{l}\text { Форма № 30, } \\
\quad \text { № } 47\end{array}$} \\
\hline Мощность поликлиник, входящих в состав больниц & \\
\hline Число коек дневных стационаров в амбулаторных условиях & \\
\hline \multicolumn{2}{|l|}{ Оснащенность медицинской техникой } \\
\hline $\begin{array}{l}\text { Обеспеченность населения компьютерными томографами (на } \\
10000 \text { среднегодовых жителей) }\end{array}$ & \multirow{4}{*}{ Форма № 30} \\
\hline $\begin{array}{l}\text { Обеспеченность населения магнитно-резонансными томогра- } \\
\text { фами (на } 10000 \text { среднегодовых жителей) }\end{array}$ & \\
\hline Обеспеченность населения маммографами (на 10000 женщин) & \\
\hline $\begin{array}{l}\text { Обеспеченность населения установками для проведения } \\
\text { радиотерапии (на } 10000 \text { среднегодового населения) }\end{array}$ & \\
\hline
\end{tabular}




\section{МАТЕРИАЛЬНО-ТЕХНИЧЕСКИЕ РЕСУРСЫ ЗДРАВООХРАНЕНИЯ}

Учебное пособие

Под редакцией профессора, академика РАН В.И. Стародубова

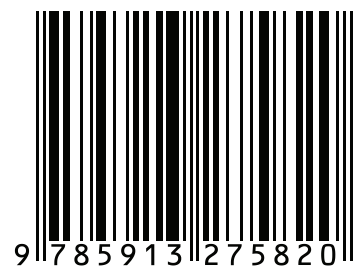

Технический редактор Кулакова Г.А.

Подписано в печать 26.04.2019

Бумага офсетная.

Гарнитура NewtonC

Формат $60 \times 841 / 16$

Печать трафаретная. Печ. л. 3,8.

Тираж 500 экз. Заказ № 013-19.

Отпечатано в типографии ИД «Академия Естествознания», 440026, г. Пенза, ул. Лермонтова, 3 